Article

\title{
$\sigma$-Bond Electron Delocalization in Oligosilanes as Function of Substitution Pattern, Chain Length, and Spatial Orientation
}

\author{
Johann Hlina ${ }^{1}$, Filippo Stella ${ }^{1}$, Mohammad Aghazadeh Meshgi ${ }^{1}$, Christoph Marschner ${ }^{1, *}$ \\ and Judith Baumgartner ${ }^{2, *}$ \\ 1 Institut für Anorganische Chemie, Technische Universität Graz, Stremayrgasse 9, A-8010 Graz, Austria; \\ johann.hlina@tugraz.at (J.H.); filippo.stella@unipd.it (F.S.); m.meshgi@ucc.ie (M.A.M.) \\ 2 Institut für Chemie, Karl Franzens Universität Graz, Stremayrgasse 9, 8010 Graz, Austria \\ * Correspondence: christoph.marschner@tugraz.at (C.M.); baumgartner@tugraz.at (J.B.); \\ Tel.: +43-316-873-32112 (C.M.); +43-316-873-32107 (J.B.); Fax: +43-316-873-1032112 (J.B.)
}

Academic Editor: Mitsuo Kira

Received: 21 July 2016; Accepted: 4 August 2016; Published: 18 August 2016

\begin{abstract}
Polysilanes are known to exhibit the interesting property of $\sigma$-bond electron delocalization. By employing optical spectroscopy (UV-vis), it is possible to judge the degree of delocalization and also differentiate parts of the molecules which are conjugated or not. The current study compares oligosilanes of similar chain length but different substitution pattern. The size of the substituents determines the spatial orientation of the main chain and also controls the conformational flexibility. The chemical nature of the substituents affects the orbital energies of the molecules and thus the positions of the absorption bands.
\end{abstract}

Keywords: oligosilanes; $\sigma$-bond electron delocalization; UV-spectroscopy; single crystal diffraction analysis

\section{Introduction}

Polysilanes, that is compounds containing Si-Si bonds, are known to exhibit optical properties similar to conjugated organic molecules [1]. However, in these compounds, it is not $\pi$-electrons that are distributed over a system of multiple bonds, but $\sigma$-electrons that are delocalized over a number of $\sigma$-bonds. For both types of delocalization it is important that the involved orbitals are spatially aligned in a way that they can overlap. For conjugated $\pi$-systems, this means that all involved atoms are located in one plane and for delocalized $\sigma$-electrons this requirement is associated with anti- or transoid conformations of the involved molecular chain $[2,3]$.

The $\sigma$ electron delocalization effect was initially discovered by the research groups of Kumada [4-6] and Gilman $[7,8]$ in the 1960s, in the course of studying UV/vis spectra of small oligosilanes. Later, longer polysilanes were found to exhibit thermochromism, where the length of aligned chain segments which absorb light of a certain wave length, changes as a function of temperature [9].

Our own studies in this field [10-17] are strongly connected to investigations concerned with the chemistry of silanides [18]. The availability of polysilanyl anions allows the construction of oligosilanes chains with defined conformational properties.

We were thus interested in studying whether it is possible to impose preferred conformations on short oligosilanes by the deliberate choice of substitution pattern. By careful variation of substituent type and shape, it should be possible to manipulate the $\sigma$-electron delocalization. 


\section{Results}

In our previous studies we learned that, while a rotational process in permethylated oligosilanes is energetically very facile, the introduction of bulky end groups such as the tris(trimethylsilyl)silyl unit (Figure 1) substantially suppresses these rotations if the groups are not too far apart [10]. This is consistent with the appearance of only one low energy UV-absorption band, which can be associated with an all-transoid conformer. With increasing chain length between two tris(trimethylsilyl)silyl units, their steric interaction diminishes and thus the force that drives the molecule to engage only in one conformer diminishes. This effect is reflected in the UV-absorption spectra by the appearance of a second low energy absorption band of higher energy for internal $\alpha, \omega$-silanylene chain units of -( $\left(\mathrm{SiMe}_{2}\right)_{5}$ - and longer, which corresponds to a conformer with a shorter transoid aligned segment [10].

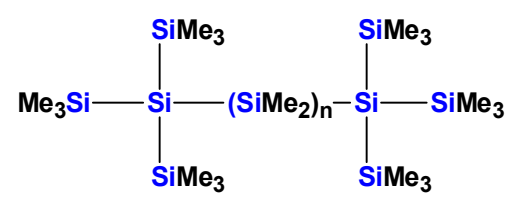

$\mathrm{n}=1,2(\mathbf{8}), 3(\mathbf{2 5}), 4,5(20), 6$

Figure 1. Oligosilanes with bulky tris(trimethylsilyl)silyl end groups.

In a subsequent study, we found that for longer chains with $\left(\mathrm{Me}_{3} \mathrm{Si}\right)_{3} \mathrm{Si}$ end groups, the formal substitution of two geminal methyl groups on internal -( $\left.\mathrm{SiMe}_{2}\right)$ - units for trimethylsilyl groups enforces the ability of the molecule to exist as a single conformer again by suppressing rotational processes. However, the thus favored conformers were found to not be all-transoid ones but consist of several transoid aligned segments which are separated by the introduced trimethylsilyl groups [13]. This behavior is exemplified in Figure 2. Additional information about conformational preferences of oligosilanes was obtained by single crystal X-ray diffraction analysis. Of course, the solid state structure of a polysilane is not necessarily identical with the structure in solution. For the cases of longer chains with a preference for only one conformer, Raman spectroscopic measurements of solution and solid state samples suggest identical conformational properties [10].

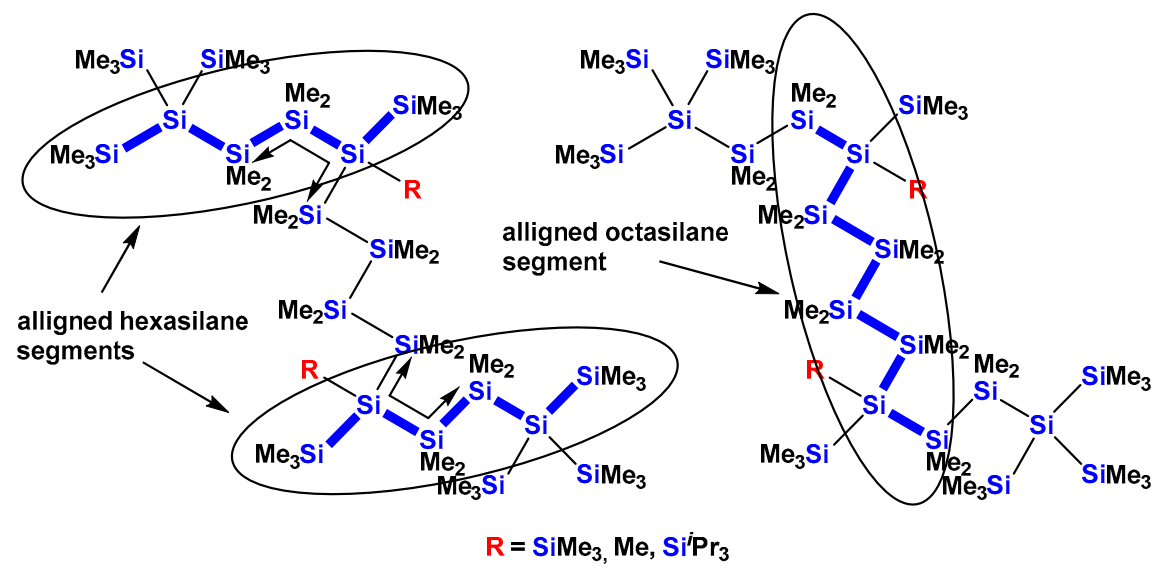

Figure 2. Schematic representation of the preferentially existing conformer of a permethylated tetradecasilane with geminal trimethylsilyl substitution at the 2, 5, 10, and 13 positions. Terminal transoid aligned hexasilane segments marked on the left side, a transoid aligned octasilane segment on the right side.

The current study can be considered as a continuation of previous work [10,13-17]. In a first part, the comparison of the UV absorption spectra of a set of hexasilanes with different substitution patterns allows a judgement of substituent influence on orbital energies and conformational properties. 
A second part deals with longer oligosilanes which are variations of the previously investigated compounds where trimethylsilyl groups are either exchanged for methyl or for triisopropylsilyl groups. A final small part is dedicated to UV-spectroscopic analysis of some cyclosilanes.

\subsection{Synthesis of Oligosilanes}

Compound 1 was obtained by simple reaction of isopropylbis(trimethylsilyl)silylpotassium [19] with isopropylchloride (Scheme 1). It is interesting to note that $\mathbf{1}$ reacts cleanly with potassium tert-butoxide to the respective 1,1-diisopropyltrimethyldisilanylpotassium. The attempt to achieve similar chemistry with octamethyltrisilane led to complicated oligomerization chemistry $[18,20]$. A likely reason for the clean conversion of $\mathbf{1}$ seems to be the increased steric demand of 1,1-diisopropyltrimethylsilanylpotassium compared to pentamethyldisilanylpotassium. Further reaction with 1,2-dichlorotetramethydisilane gave compound 2 (Scheme 1).
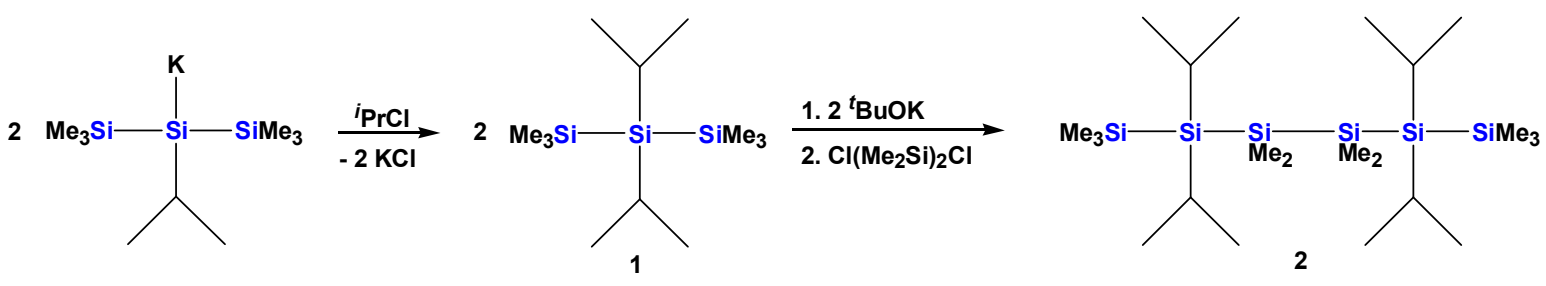

Scheme 1. Synthesis of a hexasilane with bulky isopropyl groups in the 2- and 5-positions.

Reaction of 2,5-bis(trimethylsilyl)decamethylhexasilane (3) with potassium tert-butoxide gives the silanide 4 in a clean reaction (Scheme 2). The latter can be used as building block for the construction of a series of oligosilane chains. Coupling of 2 equiv. of 4 with 1,2-dichlorotetramethyldisilane, 1,3-dichlorohexamethyltrisilane, or 1,4-dichlorooctamethyltetrasilane gave compounds 5, 6, and 7 with 12,13 , and 14 catenated silicon atoms in the main chain (Scheme 2). The strategy to prepare 5, 6, and 7 is similar to what we have reported earlier for the synthesis of $\mathbf{5 a}, \mathbf{6 a}$, and $\mathbf{7 a}$ (Figure 3) [13].
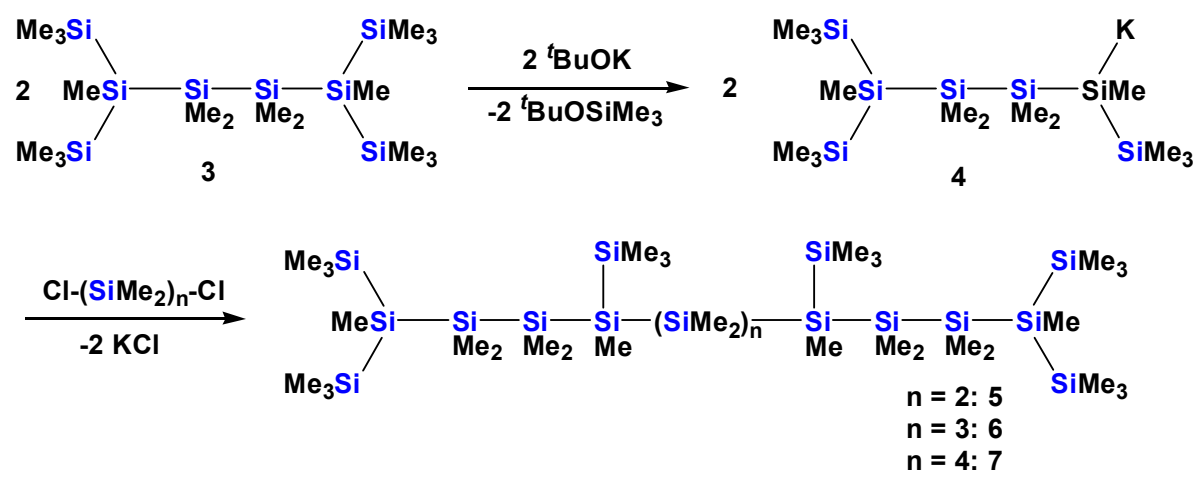

Scheme 2. Synthesis of elongated oligosilanes with trimethylsilyl substituents in the core and at the periphery of the chains.

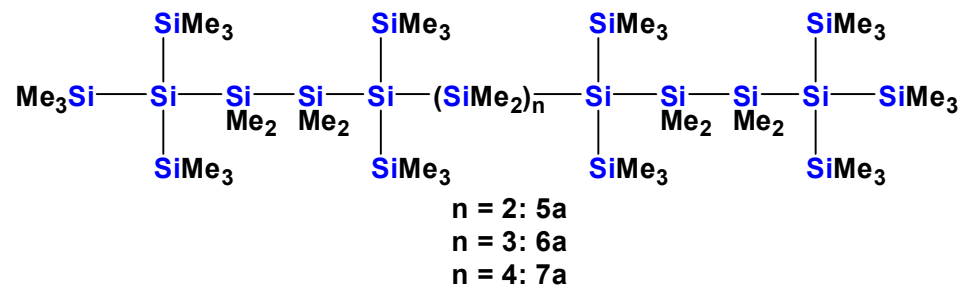

Figure 3. Compounds $5 \mathbf{a}, \mathbf{6 a}$, and $7 \mathbf{a}$ serve as reference standards for the judgement of the optical properties of the two series of oligosilanes 5,6 , and 7 as well as 11, 12, and 13 . 
The latter were prepared from 2,2,5,5-tetrakis(trimethylsilyl)decamethylhexasilane (8) and contain tris(trimethylsilyl)silyl end groups and bis(trimethylsilyl)silylene units in the main chain, which were found to cause a turn in the main chain, interrupting an all-transoid conformation.

Another strategy for the manipulation of conformational properties of oligosilanes chains aims in the opposite direction. Instead of replacing trimethylsilyl units by methyl groups and thus creating more flexible chains, it is possible to increase the steric influence of substituents by replacing trimethylsilyl groups with triisopropylsilyl groups. Starting from 2,5-bis(triisopropylsilyl)-2,5bis(trimethylsilyl)decamethylhexasilane (9) reaction with potassium tert-butoxide gives the respective silanide $\mathbf{1 0}$ in a clean reaction (Scheme 3). Two equiv. of $\mathbf{1 0}$ can be coupled to the elongated oligosilanes 11, 12, and 13 (Scheme 3).

2<smiles>C[SiH](C)[Si](C)([SiH3])[SiH2][Si](C)([SiH3])[SiH2][SiH3]</smiles>

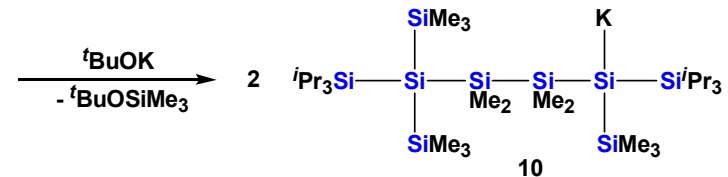

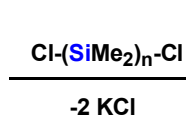

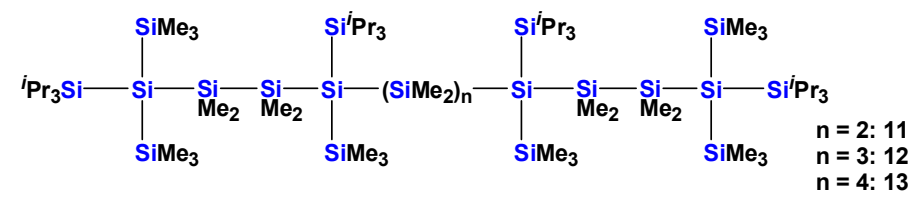

Scheme 3. Synthesis of elongated oligosilanes with trimethylsilyl and triisopropylsilyl substituents in the core and at the periphery of the chains.

Compound 14 represents an oligosilanes chain which contains bis(trimethylsilyl)silylene units in the core of the chain as in the compounds of the previous study but features bis(trimethylsilyl)methylsilyl end groups instead of tris(trimethylsilyl)silyl groups. The compound was prepared by reaction of 2,5-bis(trimethylsilyl)undecamethylhexasilanyl-2-potassium with 1,2-dichlorotetramethyldisilane (Scheme 4).
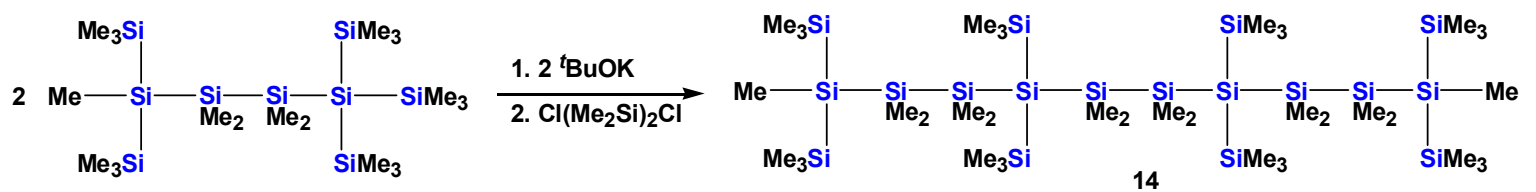

Scheme 4. Synthesis of a dodecasilane chain with two internal bis(trimethylsilyl)silylene units and bis(trimethylsilyl)methylsilyl end groups.

In our studies, we found that the simply accessible 2,2,5,5-tetrakis(trimethylsilyl) decamethylhexasilane (8) is a conformationally rather rigid molecule. Since analogous compounds are easily available, it was tempting to prepare a number of compounds of molecules with different end groups $(\mathbf{1 5}, \mathbf{1 6}, \mathbf{1 7})$ (Scheme 5). Compound 18 with phenyl groups on the 1,2-disilanylene unit (Figure 4) was synthesized in a similar way by reaction of tris(trimethylsilyl)silyl potassium with the 1,2-ditriflate obtained from 1,2-dimethyltetraphenyldisilane. Also, compound 19 was prepared in a similar way (Scheme 5) and was then converted further to compound 20 by $\mathrm{AlCl}_{3}$ catalyzed isomerization (Figure 4) [21].

Compound 9 was also converted into a 1,4-disilandiide by reaction with 2 equiv. potassium tert-butoxide. Its reaction with 1,2-dichlorotetramethyldisilane leads to a mixture of the two isomers 21a and 21b, where the triisopropylsilyl groups are either cis- or trans-oriented to each other (Scheme 6). In a related way, compound 18 was converted to the 1,4-disilanide, which was further reacted with dimethyldichlorosilane to give the cyclopentasilane 22 (Figure 4). 


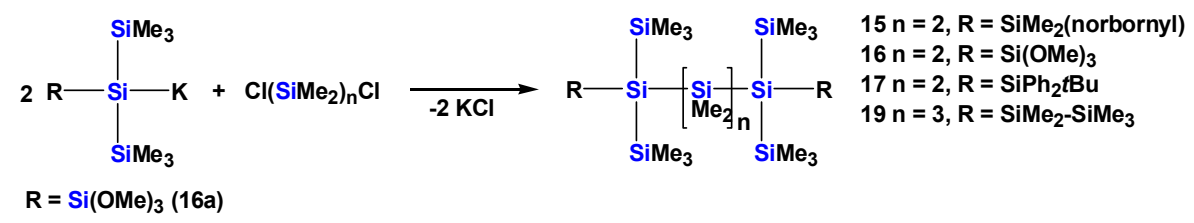

Scheme 5. Synthesis of a number of oligosilanes with derivatized tris(trimethylsilyl)silyl groups and $\alpha, \omega$-oligosilanylene units of different lengths.

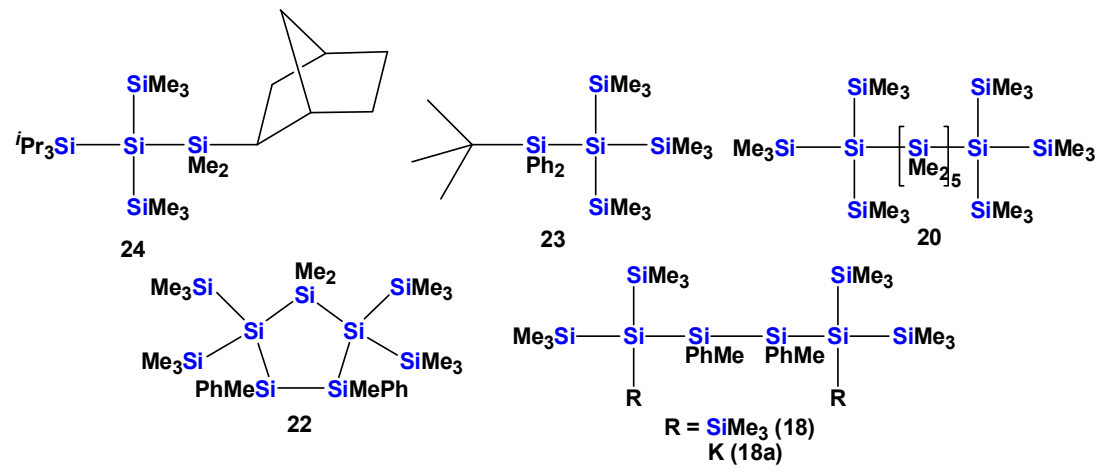

Figure 4. Some new compounds prepared in this study either as starting materials or as subjects for UV-spectroscopic studies.

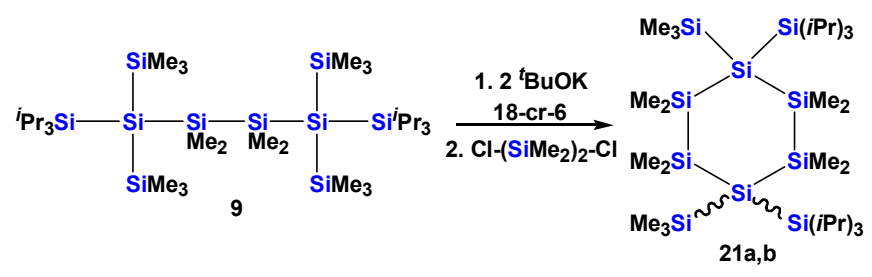

Scheme 6. Use of 2,5-bis(trimethylsilyl)-2,5-bis(triisopropylsilyl)decamethylhexasilane for the synthesis of a mixture of cis- and trans-1,4-bis(triisopropylsilyl)-1,4-bis(trimethylsilyl)cyclohexasilane.

Compound 23 (Figure 4) was prepared as starting material for the synthesis of $\mathbf{1 7}$ and compound 24 was used for structural comparison purposes.

\subsection{UV-Spectroscopy Studies}

$\mathrm{UV} /$ vis spectroscopy is a good tool to achieve some insight into the $\sigma$-electron delocalization in polysilanes. The position of the lowest energy absorption band allows making an estimate about the extension of delocalization. Effective $\sigma$-electron delocalization requires a transoid orientation of the polysilane chain $[3,22]$. If the transoid arrangement is broken by bending the chain into another direction, electron delocalization is interrupted. This was experimentally verified by Tsuji and Tamao in a series of elegant publications, where they were able to lock polysilane conformations by introducing a rigid backbone [23-27]. Our own studies $[10,13,17]$ have shown that it is possible to prepare polysilanes with restricted rotational properties, which contain two or three different segments which exhibit $\sigma$-electron delocalization but are separated by a rotational twist. In the current study, we aim to investigate the steric and electronic influence of substituents on conformational and delocalization properties.

Scheme 6 and Figure 4 show a number of hexasilanes with different substitution pattern. While it is known that the permethylated $n$-hexasilane $\left(n-\mathrm{Si}_{6} \mathrm{Me}_{14}\right)$ exhibits a $\lambda_{\max }$ at $260 \mathrm{~nm}[6,28]$, the respective band for $\mathbf{8}$, which is an $n$-hexasilane with four trimethylsilyl groups in the 2- and 5-positions, is slightly blue-shifted to $257 \mathrm{~nm}$ (Figure 5, Table 1) [10]. There are two possible explanations for this slight shift. On one hand, the bulk of the tris(trimethylsilyl)silyl groups largely suppresses rotation 
around internals Si-Si bonds and thus locks the conformation of 8 to an all-transoid arrangement. This enhances the absorption ability of the chain because many of the energetically accessible conformations of $n-\mathrm{Si}_{6} \mathrm{Me}_{14}$ contain segments that are not fully delocalized. On the other hand, it needs to be taken into consideration that unfavorable 1,4-interactions of the bulky tris(trimethylsilyl)silyl groups also prevent the molecule from engaging in an all-anti conformation. It seems, however, that this special conformation, which corresponds to a perfect $\sigma$-electron delocalization is accessible for $n$-Si ${ }_{6} \mathrm{Me}_{14}$. Apart from this steric explanation model, also the different electronic properties of silyl and alkyl groups should to be taken into consideration. As the $\sigma$-electron delocalization process involves $\sigma^{*}$-orbitals of the Si-substituents bonds the energy of these is relevant.

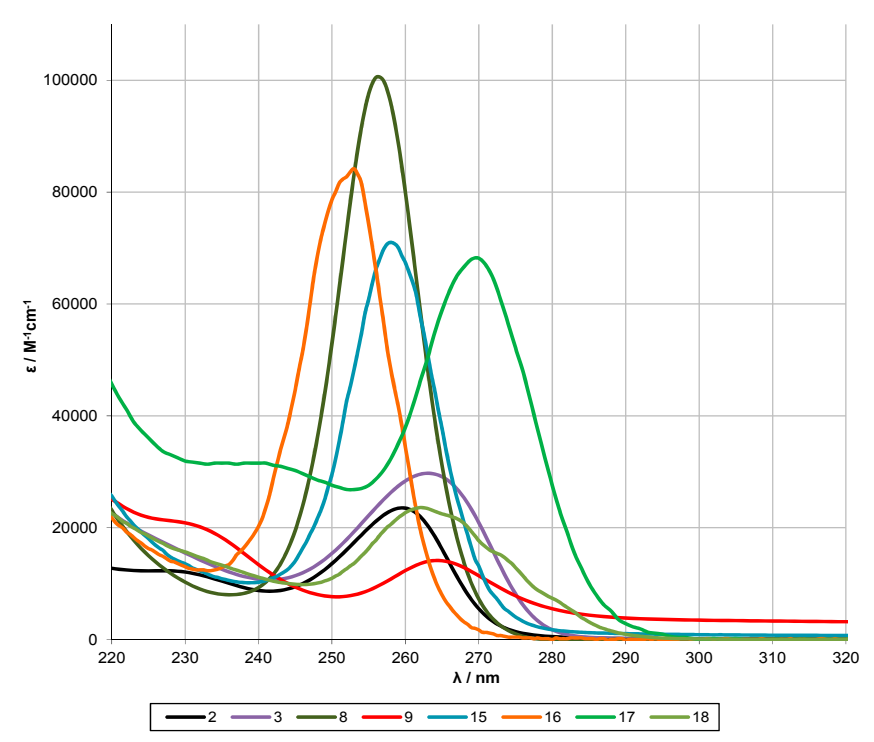

Figure 5. Comparison of the UV spectra of differently substituted hexasilanes.

Table 1. UV spectroscopic data of some selected oligosilanes.

\begin{tabular}{cccccccc}
\hline Compound & $\begin{array}{c}\text { Oligosilane } \\
\text { Chain Length }\end{array}$ & $\begin{array}{c}\lambda_{\mathbf{1}} \\
{[\mathbf{n m}]}\end{array}$ & $\begin{array}{c}\varepsilon_{1} \\
{\left[\mathbf{M}^{-1} \cdot \mathbf{c m}^{-1}\right]}\end{array}$ & $\begin{array}{c}\lambda_{2} \\
{[\mathbf{n m}]}\end{array}$ & $\begin{array}{c}\varepsilon_{2} \\
{\left[\mathbf{M}^{-1} \cdot \mathbf{c m}^{-1}\right]}\end{array}$ & $\begin{array}{c}\lambda_{3} \\
{[\mathbf{n m}]}\end{array}$ & $\begin{array}{c}\varepsilon_{3} \\
{\left[\mathbf{M}^{-1} \cdot \mathbf{c m}^{-1}\right]}\end{array}$ \\
\hline$n-\mathbf{S i}_{\mathbf{6}} \mathbf{M e}_{\mathbf{1 4}}[6]$ & 6 & 260 & $1.4 \times 10^{4}$ & & & & \\
$\mathbf{8}[10]$ & 6 & 257 & $6.6 \times 10^{4}$ & - & - & - & - \\
$\mathbf{2}$ & 6 & 260 & $2.4 \times 10^{4}$ & & & & \\
$\mathbf{3}[29]$ & 6 & 264 & $3.0 \times 10^{4}$ & & & & \\
$\mathbf{9}$ & 6 & 264 & $1.4 \times 10^{4}$ & & & & \\
$\mathbf{1 5}$ & 6 & 258 & $7.1 \times 10^{4}$ & & & & \\
$\mathbf{1 6}$ & 6 & 253 & $8.4 \times 10^{4}$ & & & \\
$\mathbf{1 8}$ & 6 & 262 & $2.4 \times 10^{4}$ & & & & \\
$\mathbf{1 7}$ & 6 & 270 & $6.8 \times 10^{4}$ & 240 & $3.2 \times 10^{4}$ & & \\
$\mathbf{2 5}[10]$ & 7 & 269 & $6.2 \times 10^{4}$ & - & & & \\
$n-\mathbf{S i}_{\mathbf{1 2}} \mathbf{M e}_{\mathbf{2 6}}[28]$ & 12 & 290 & & & & & \\
$\mathbf{5 a}[13]$ & 12 & $\sim 289(\mathrm{sh})$ & $2.3 \times 10^{4}$ & 259 & $7.4 \times 10^{4}$ & & \\
$\mathbf{5}$ & 12 & 268 & $1.6 \times 10^{4}$ & 218 & $3.2 \times 10^{4}$ & & \\
$\mathbf{1 1}$ & 12 & 264 & $5.1 \times 10^{4}$ & 232 & & 216 & $3.1 \times 10^{4}$ \\
$\mathbf{1 4}$ & 12 & 265 & $5.0 \times 10^{4}$ & & & & \\
$\mathbf{6 a}[13]$ & 13 & $\sim 295(\mathrm{sh})$ & $1.8 \times 10^{4}$ & 278 & $5.6 \times 10^{4}$ & 258 & $7.3 \times 10^{4}$ \\
$\mathbf{6}$ & 13 & $\sim 287(\mathrm{sh})$ & $1.3 \times 10^{4}$ & 272 & $1.7 \times 10^{4}$ & 212 & $2.7 \times 10^{4}$ \\
$\mathbf{1 2}$ & 13 & $\sim 307(\mathrm{sh})$ & $3.1 \times 10^{3}$ & $\sim 283(\mathrm{sh})$ & $2.6 \times 10^{4}$ & 267 & $4.6 \times 10^{4}$ \\
$7 \mathbf{2}[13]$ & 14 & $\sim 303(\mathrm{sh})$ & $1.8 \times 10^{4}$ & 286 & $7.8 \times 10^{4}$ & 259 & $9.5 \times 10^{4}$ \\
$\mathbf{7}$ & 14 & 285 & $2.4 \times 10^{4}$ & 222 & $3.6 \times 10^{4}$ & & \\
$\mathbf{1 3}$ & 14 & $\sim 311(\mathrm{sh})$ & $1.5 \times 10^{4}$ & 293 & $3.8 \times 10^{4}$ & 268 & $4.5 \times 10^{4}$ \\
$\mathbf{2 7}[13]$ & 9 & $\sim 284(\mathrm{sh})$ & $1.2 \times 10^{4}$ & 262 & $9.2 \times 10^{4}$ & & \\
$\mathbf{1 9}$ & 9 & 273 & $3.6 \times 10^{4}$ & 230 & $1.9 \times 10^{4}$ & 226 & $2.1 \times 10^{4}$ \\
$\mathbf{2 0}$ & 9 & 288 & $4.0 \times 10^{4}$ & 271 & $2.7 \times 10^{4}$ & 246 & $1.7 \times 10^{4}$ \\
\hline
\end{tabular}

To estimate which effect is more pronounced compounds 2, 3, and 9 are of interest. Compound 2, with four bulky isopropyl groups in the 2- and 4-positions, can be considered electronically equivalent 
to $n-\mathrm{Si}_{6} \mathrm{Me}_{14}$ and sterically similar to 8 . The fact that the absorption maximum of 2 is identical with that of $n-\mathrm{Si}_{6} \mathrm{Me}_{14}$ seems to indicate that conformational properties of these two compounds are similar. Compound 9 is similar to $\mathbf{8}$ but two of the trimethylsilyl groups are replaced by triisopropylsilyl groups. However, the crystal structure of 9 shows a first torsional angle of $\mathrm{w}_{1}=168^{\circ}$ compared to $159^{\circ}$ found for 8 . This seems to indicate a better transoid alignment of the chain, which results in a bathochromic shift of $7 \mathrm{~nm}$ to a low energy absorption maximum of $264 \mathrm{~nm}$ (Table 1, Figure 5). Interestingly enough, compound $\mathbf{3}$ where the same trimethylsilyl groups of 8 are replaced by methyl groups also exhibits its low energy absorption maximum at $264 \mathrm{~nm}$ (Table 1, Figure 5). It almost seems as if the tris(trimethylsilyl)silyl groups of $\mathbf{8}$ are particularly ill-suited for a transoid alignment of the chain. Even compound 15, where two of the trimethylsilyl groups of 8 are replaced by dimethyl-exo-2-norbornylgroups, shows a slight bathochromic shift of the low energy absorption maximum to $258 \mathrm{~nm}$ (Table 1, Figure 5).

Compound 16 represents another example of formal exchange of two of the trimethylsilyl groups of 8 . This time $\mathrm{Si}(\mathrm{OMe})_{3}$ are introduced. Despite the fact that there are conformations for 16, where the transoid aligned chain contains trimethylsilyl end-groups, a hypsochromic shift of the low energy absorption maximum is observed (Table 1, Figure 5). It seems evident that this is an electronic effect, caused by the less electron donating $\mathrm{Si}(\mathrm{OMe})_{3}$ groups. In contrast to this, compound 17, where the two trimethylsilyl groups are replaced by $\mathrm{SiPh}_{2}{ }^{t} \mathrm{Bu}$ units, exhibits the most bathochromicly shifted absorption maximum at $270 \mathrm{~nm}$ (Table 1, Figure 5). Although the crystal structure of 17 (Table 2) does not indicate a substantially better aligned chain, it can be assumed that the phenyl groups of $\mathbf{1 7}$ are responsible for an extension of the delocalization. The introduction of phenyl groups into the spacer unit as can be seen in compound $\mathbf{1 8}$ has only a minor effect on the location of the absorption maximum (Table 1, Figure 5).

Figures 6 and 7 provide insight to judge the effectivity of internal substituents of longer oligosilanes to control the conformation by their UV-spectra. Figure 6 shows a comparison of compounds 5, 6, and 7 with the respective compounds $\mathbf{5 a}, \mathbf{6 a}$, and 7a [13] which possess tris(trimethylsilyl)silyl end groups and internal bis(trimethylsilyl)silylene units. The higher degree of these elements compared to bis(trimethylsilyl)methylsilyl end groups and internal trimethylsilylmethylsilylene units render $5 \mathbf{a}$, 6a, and 7a more rigid, whereas 5, 6, and 7 are more flexible and thus are able to engage in different conformations. This difference is nicely reflected in the UV spectra. The spectra of $\mathbf{5 a}$ and, in particular, 6a and 7a display relatively sharp bands, which can be assigned to defined delocalized segments of the molecules. For 5, 6, and 7, the corresponding bands are much broader indicating contributions of conformations consisting of more than two separated extended delocalized segments.

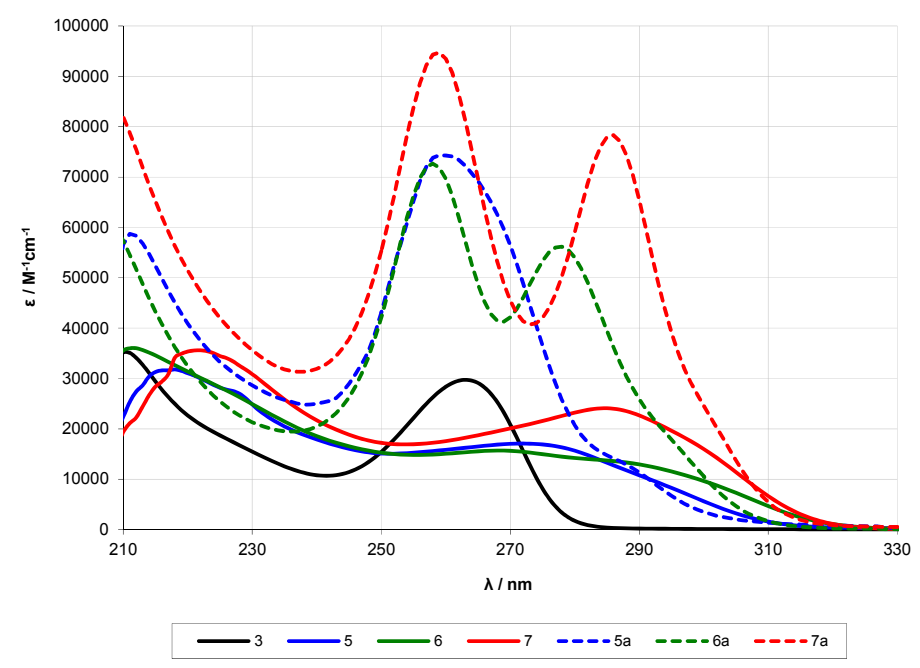

Figure 6. Comparison of the UV spectra of different dodeca-, trideca-, and tetradecasilanes with either methyl or trimethylsilyl groups in terminal and internal positions. 
Interestingly, the picture of Figure 7 is quite different from that in Figure 6. While the latter shows the effect of increased conformational flexibility, Figure 7 features the impact of even stronger enforced conformational locking which is accomplished by exchanging some of the trimethylsilyl for triisopropylsilyl groups. A first consequence of this exchange was already visible in the comparison of 8 with 9 (Figure 5). In this case, the exchange of peripheral trimethylsilyl groups for triisopropylsilyl units resulted in a bathochromic shift of the low energy absorption maximum of $7 \mathrm{~nm}$. Related red-shift behavior is also visible for 11, 12, and 13.

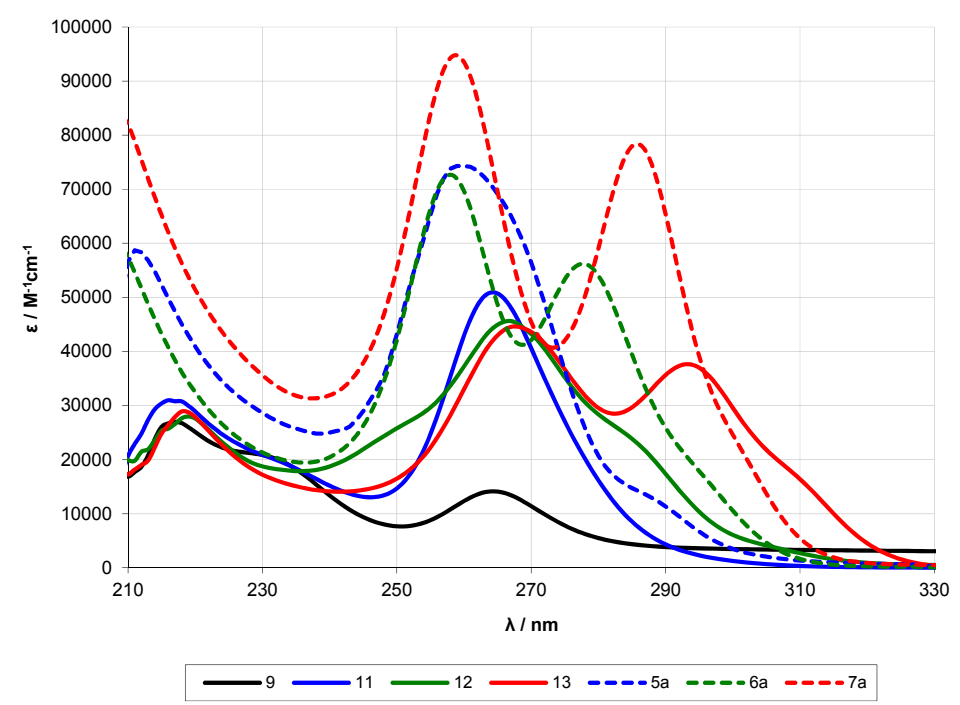

Figure 7. Comparison of the UV spectra of different dodeca-, trideca-, and tetradecasilanes with either triisopropylsilyl or trimethylsilyl groups in terminal and internal positions.

Figure 8 shows the UV spectra of compounds 19, 20, and 25. Compounds 19 and 20 are not only isomers but the main chains of both compounds are nonasilanes. Compound 19 contains two pentamethyldisilanyl units and an internal 1,3-trisilanylene unit, whereas Compound 20 has two tris(trimethylsilyl)silyl units and an internal 1,5-pentasilanylene unit. The UV-spectra of 19 and 20 suggest that the conformations of these two oligosilanes at ambient temperature are quite different. The low energy absorption maximum of 19 is at $273 \mathrm{~nm}$ corresponding to an aligned heptasilane fragment. This seems to indicate that the pentamethyldisilanyl units do not participate in the delocalized segment. One reason for this is a likely easy rotation around the Si-Si bonds. Another reason might be that the pentamethyldisilanyl is not inclined to stretch out but to bend back toward the main body of the molecule. Such behavior had been observed by Apeloig and co-workers for the tris(pentamethyldisilanyl)silyl unit and was described as an umbrella effect [30].

Compound 20 on the other hand exhibits two distinct absorption bands at 271 and at $288 \mathrm{~nm}$. The latter can be considered as the low energy absorption maximum of an aligned nonasilane [13] whereas a band around $270 \mathrm{~nm}$ hints at a aligned heptasilane segment. The existence of a second conformer in tris(trimethylsilyl)silyl terminated silanes was observed before for 2,2,9,9-tetrakis (trimethylsilyl)octadecamethyldecasilane, where a decasilane band was accompanied by an octasilane band [10]. The reason for the effect of two distinct conformers is that, for spacer lengths of more than four dimethylsilylene units, the steric bulk of the two tris(trimethylsilyl)silyl end groups is not sufficient to align the whole molecule. The UV spectrum of 2,2,6,6-tetrakis(trimethylsilyl) dodecamethylheptasilane (25), which is also seen in Figure 8 tells us that for $\mathbf{1 9}$ at least some degree of improved alignment is existent as evidence of a slight bathochromic shift of the low energy absorption band from 269 to $273 \mathrm{~nm}$. 


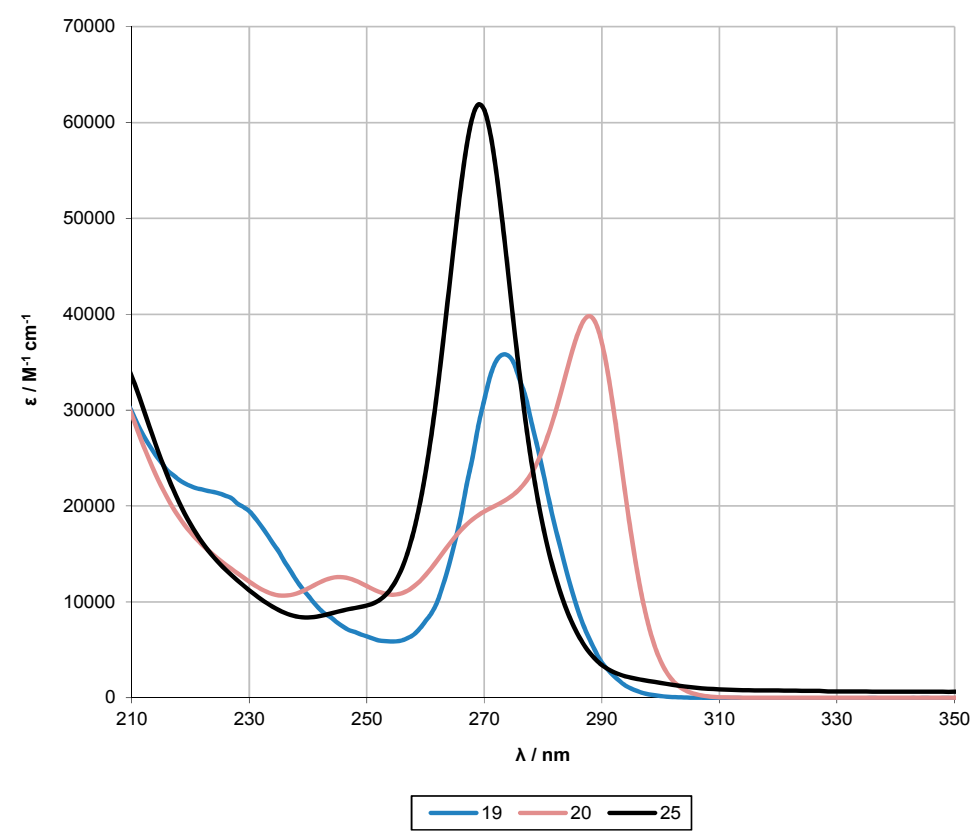

Figure 8. Comparison of the UV spectra of the isomeric compounds $\mathbf{1 9}$ and 20 and compound 25, which can be regarded as the core of compound 19 .

The nonasilane band of 20 can also be compared to 2,2,5,5,8,8-hexakis(trimethylsilyl) decamethylnonasilane (27) (Table 1) [13], where the two methyl groups at the central silicon atom of the compound are replaced by trimethylsilyl groups. The nonasilane absorption band associated with 27 is only visible as a shoulder and the spectrum is dominated by a prominent hexasilane band [13].

The UV spectra shown in Figure 9 are those of 5, 5a, and $\mathbf{1 4}$ in addition to compound 8. We have discussed the difference between 5 and $5 a$ already above. Compound $\mathbf{1 4}$ contains the end-groups of $\mathbf{5}$ and the core of $\mathbf{5 a}$. Compared to $\mathbf{5 a}$, the UV spectrum of $\mathbf{1 4}$ shows a bathochromic shift associated with a higher conformational flexibility but the degree of this shift is not as distinct as observed for 5 . This is also emphasized by the shape of the absorption band, which suggests still the presence of a conformational preference. Again, the band of compound 8 tells us that the predominant conformations of 5, 5a, and 14 include segments longer or better aligned than the hexasilane unit in 8 .

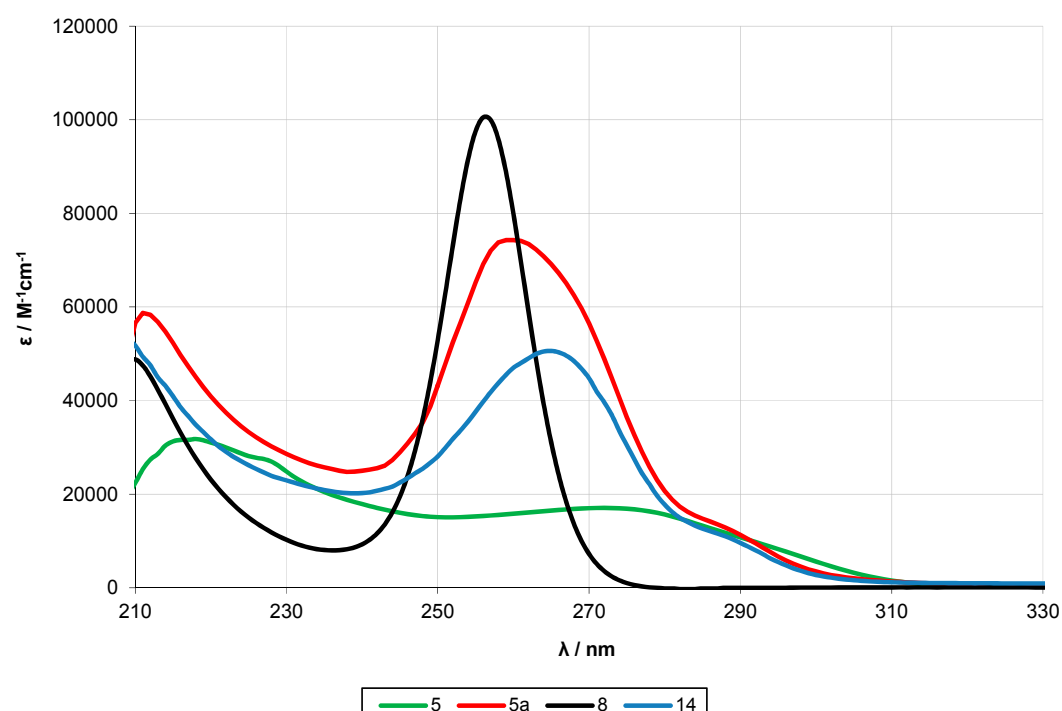

Figure 9. Comparison of the UV spectra of different dodecasilanes $(\mathbf{5}, \mathbf{5 a}, \mathbf{1 4})$ and compound 8. 
The last UV comparison of this study is between cyclosilanes 21a, 21b, 22, and 26 (Figure 10). From seminal work by West and co-workers, it is known that the UV absorption behavior of permethylated cyclosilanes exhibits a trend of hypsochromic shifts for compounds with increasing ring sizes up to the cyclononasilane [31]. Our own studies, however, have shown that UV absorption behavior of trimethylsilyl-substituted cyclosilanes is different from that of permethylated cyclosilanes of the same ring size. Spectroscopic analysis suggested that $\sigma$-electron delocalization occurs along chain segments in the ring reaching from one trimethylsilyl group to the other [32]. Using this model for 1,1,4,4,-tetrakis(trimethylsilyl)octamethylcyclohexasilane (26) [33,34], a band around 255 nm should be observed. This is indeed true as an absorption maximum is observed at $260 \mathrm{~nm}$ (Figure 10).

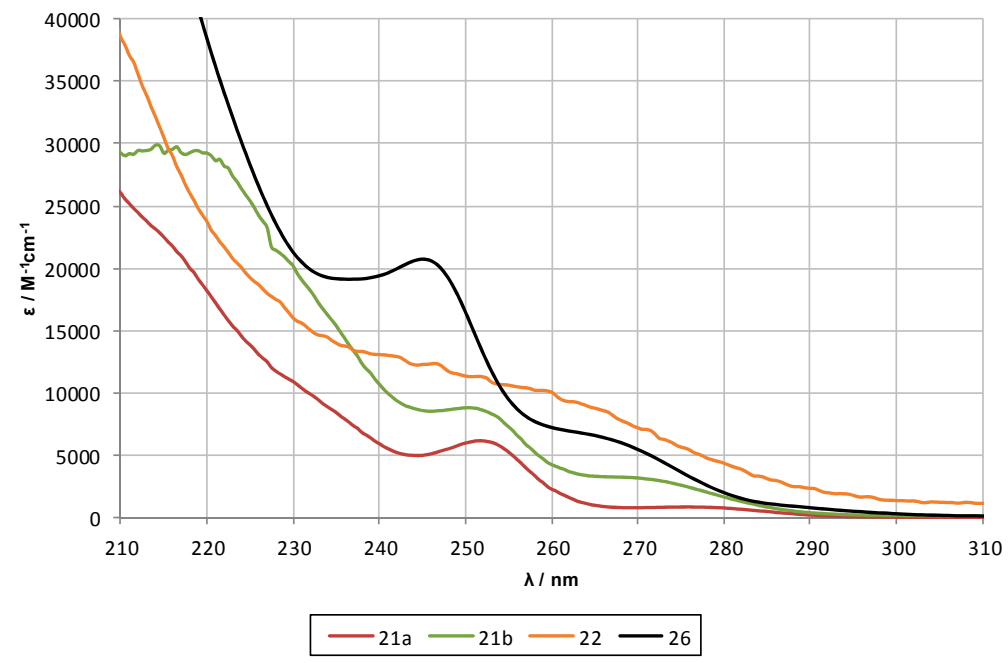

Figure 10. Comparison of the UV spectra of cyclosilanes 21a, 21b, 22, 23, 24, and 26.

The spectra for $\mathbf{2 1 a}$ and $\mathbf{2 1 b}$ hexasilane bands should be similar but the associated bands are

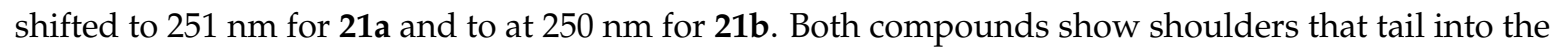
more bathochromic region. The UV spectrum of 22 is meaningful (Figure 10). Despite some absorption resembling that of $\mathbf{2 6}$, the absorption features are less pronounced. It is not exactly clear whether this absorption behavior is that of the cyclosilane core or includes interaction with its phenyl substituents.

\subsection{X-ray Crystallography}

Compounds 9 (Figure 11), 14 (Figure 12), 15 (Figure 13), 16a (Figure 14), 17 (Figure 15), 18 (Figure 16), 18a (Figure 17), 21a (Figure 18), 21b (Figure 19), 22 (Figure 20), 23 (Figure 21), and 24 (Figure 22) of this study were characterized by X-ray single-crystal structure analysis (for tables concerning crystallographic information see: Supplementary Information). As numerous related polysilanes structures are already known, these compounds provide an excellent opportunity to compare structural properties of organooligosilanes.

Compounds 9, 14, 18, 15, and 17 are oligosilanes with longer chains and their structure in the solid state can provide insight into the effectiveness of $\sigma$-electron delocalization.

The structures of compounds with a 1,2-disilanylene spacer between the tris(trimethylsilyl)silyl groups were found to crystallize in monoclinic space groups for $\mathbf{9}$ and $\mathbf{1 8}$ and the triclinic space group P-1 for 15 and 17. For all compounds, an inversion center between the two central silicon atoms was found. The asymmetric units of $\mathbf{1 5}$ and $\mathbf{1 7}$ are containing only two half molecules. The structures of three other compounds with a 1,2-disilanylene spacers between the tris(trimethylsilyl)silyl or -germyl groups were reported to be triclinic (P-1), namely 1,1,1,4,4,4-hexakis(trimethylsilyl)-2,2,3,3tetramethyltetrasilane [35], 1,2-bis[tris(trimethylsilyl)germyl]tetramethyldisilane [36], and 1,2-bis[tris (trimethylsilyl)germyl]tetramethyldigermane [36]. 


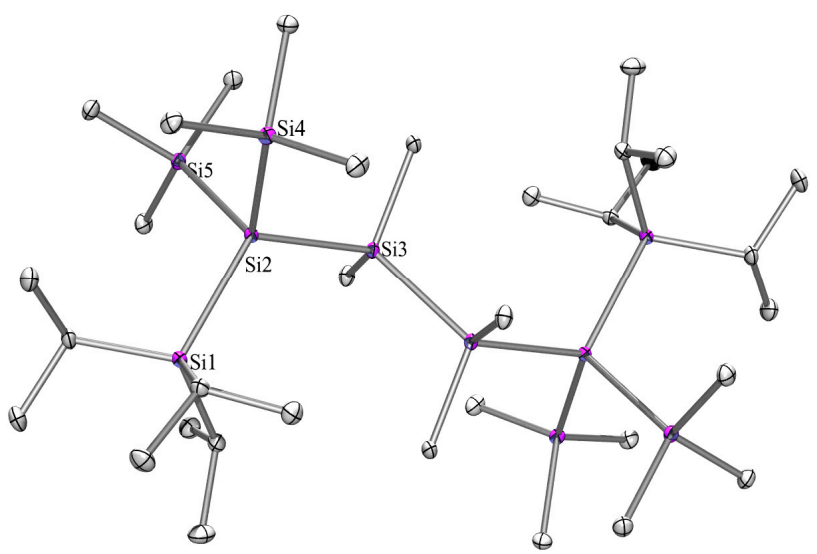

Figure 11. Crystal structure of 9. Thermal ellipsoids are represented at the 30\% level and hydrogen atoms have been omitted for clarity (bond lengths in $\AA$, angles in deg). Si(1)-C(1) 1.9106(17), $\operatorname{Si}(1)-\operatorname{Si}(2)$ 2.3945(7), Si(2)-Si(4) 2.3764(7), Si(2)-Si(3) 2.4043(9), Si(3)-Si(3A) 2.3943(9), Si(4)-Si(2)-Si(5) 103.71(3), $\mathrm{Si}(4)-\mathrm{Si}(2)-\mathrm{Si}(1)$ 112.86(3), Si(5)-Si(2)-Si(1) 108.66(3), Si(4)-Si(2)-Si(3) 108.10(3), Si(5)-Si(2)-Si(3) 103.58(2), $\operatorname{Si}(1)-\operatorname{Si}(2)-\operatorname{Si}(3)$ 118.52(3), $\operatorname{Si}(3 \mathrm{~A})-\operatorname{Si}(3)-\operatorname{Si}(2) 121.66(3)$.

The longer polysilane $\mathbf{1 4}$ also crystallizes in the triclinic space group P-1 again with an inversion center in the silicon backbone. Its main chain is divided into three segments which was observed earlier with similar structures [13]. After the bis(trimethylsilyl)silylene unit, the skeleton makes a turn adopting a torsional angle of $83^{\circ}$. Table 2 reports the conformational properties of the oligosilanes by listing the torsional angles along the main chain. The conformations of $\mathbf{9}, \mathbf{1 8}, \mathbf{1 5}$, and 17 can be described as transoid-anti-transoid (TAT) [2].

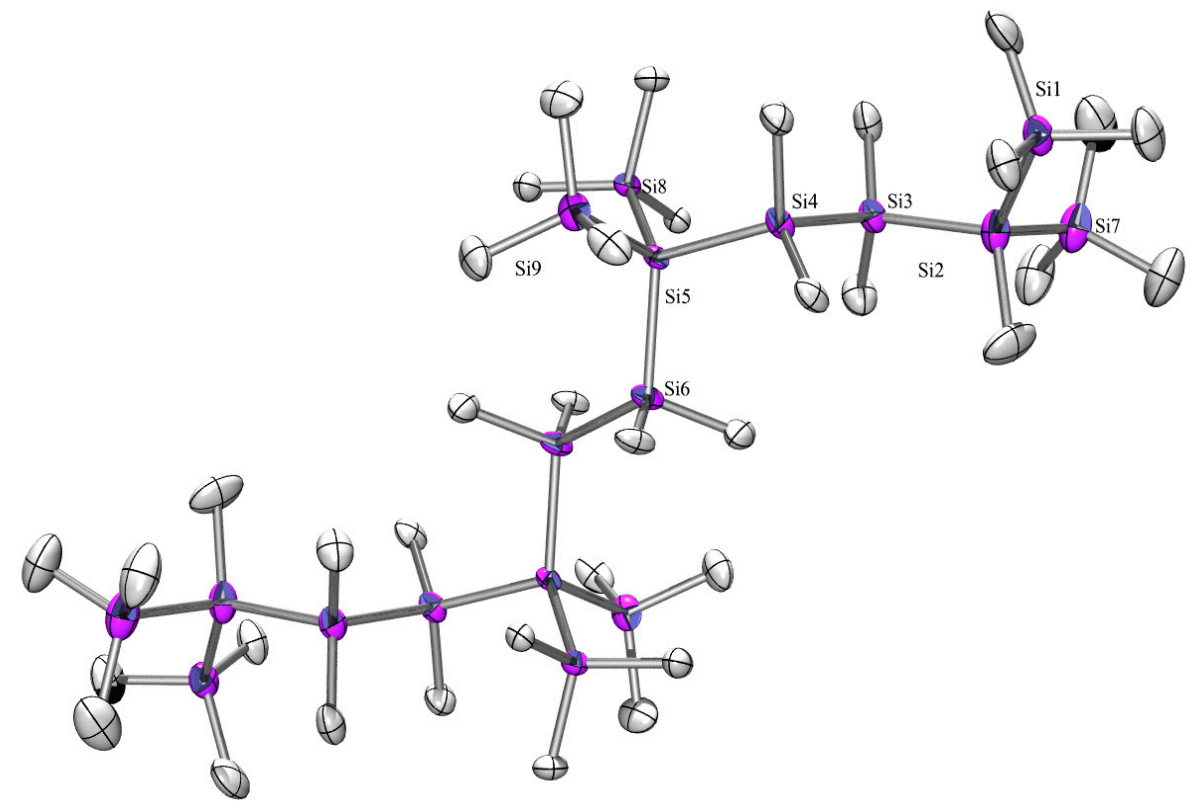

Figure 12. Crystal structure of 14. Thermal ellipsoids are represented at the $30 \%$ level and hydrogen atoms have been omitted for clarity (bond lengths in $\AA$, angles in deg). $\mathrm{Si}(1)-\mathrm{C}(1)$ 1.875(11), $\mathrm{Si}(1)-\mathrm{Si}(2)$ 2.358(5), Si(2)-Si(7) 2.333(5), Si(2)-Si(3) 2.357(4), Si(3)-Si(4) 2.342(4), Si(4)-Si(5) 2.379(3), Si(5)-Si(8) 2.354(3), Si(5)-Si(9) 2.371(3), Si(5)-Si(6) 2.376(3), Si(7)-Si(2)-Si(3) 108.05(16), Si(7)-Si(2)-Si(1) 109.16(18), Si(3)-Si(2)-Si(1) 116.28(17), Si(4)-Si(3)-Si(2) 111.55(15), Si(3)-Si(4)-Si(5) 117.83(13), Si(8)-Si(5)-Si(9) 107.50(13), $\quad \mathrm{Si}(8)-\operatorname{Si}(5)-\operatorname{Si}(6) \quad 116.91(12) ， \quad \mathrm{Si}(9)-\operatorname{Si}(5)-\operatorname{Si}(6) \quad 109.33(14), \quad \mathrm{Si}(8)-\operatorname{Si}(5)-\operatorname{Si}(4) \quad 110.18(12)$, $\mathrm{Si}(9)-\operatorname{Si}(5)-\operatorname{Si}(4)$ 103.60(13), $\operatorname{Si}(6)-\operatorname{Si}(5)-\operatorname{Si}(4)$ 108.51(13). 


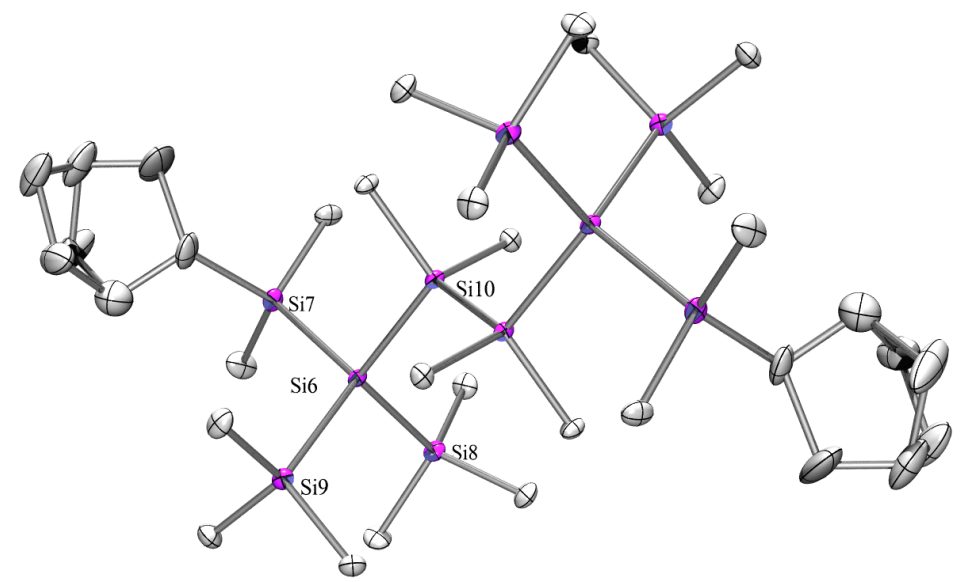

Figure 13. Crystal structure of 15. Thermal ellipsoids are represented at the $30 \%$ level and hydrogen atoms have been omitted for clarity (bond lengths in $\AA$, angles in deg). $\operatorname{Si}(6)-\operatorname{Si}(9) 2.3357(19), \operatorname{Si}(6)-\operatorname{Si}(8)$ 2.3460(17), Si(6)-Si(7) 2.357(2), Si(6)-Si(10) 2.3694(17), Si(7)-C(18) 1.869(6), Si(9)-Si(6)-Si(8) 107.60(7), $\mathrm{Si}(9)-\operatorname{Si}(6)-\operatorname{Si}(7)$ 109.89(7), Si(8)-Si(6)-Si(7) 105.08(7), Si(9)-Si(6)-Si(10) 114.57(6), Si(8)-Si(6)-Si(10) 112.08(7), $\operatorname{Si}(7)-\operatorname{Si}(6)-\operatorname{Si}(10)$ 107.21(6).

Table 2. Conformational properties of oligosilanes described as the torsional angles of the main chain.

\begin{tabular}{ccccccc}
\hline Compound & $\boldsymbol{\omega}_{\mathbf{1}}$ & $\boldsymbol{\omega}_{\mathbf{2}}$ & $\boldsymbol{\omega}_{\mathbf{3}}$ & $\boldsymbol{\omega}_{\mathbf{4}}$ & $\boldsymbol{\omega}_{\mathbf{5}}$ & Conformation \\
\hline $\mathbf{8}[10,37]$ & 159 & 180 & 159 & & & TAT \\
$\mathbf{9}$ & 168 & 180 & 168 & & & TAT \\
$\mathbf{1 4}$ & 178 & 158 & -83 & 159 & 180 & ATOTATOTA \\
$\mathbf{1 8}$ & 162 & 180 & 162 & & & TAT \\
$\mathbf{1 5}$ & $160 / 161$ & 180 & $160 / 161$ & & & TAT \\
$\mathbf{1 7}$ & $160 / 160$ & 180 & $160 / 160$ & & & TAT \\
\hline
\end{tabular}

It should be noted that the first torsional angle of $\mathbf{9}$ is with $168^{\circ}$ more transoid than those of $\mathbf{1 8}$, 15 and 17. Given the fact that 9 exhibits the most bathochromicly shifted absorption band of the structurally related permethylated compounds, this might be in part caused by a more effective delocalization. The structure of $\mathbf{1 4}$ is particularly interesting. Judging the torsional angles, an ATOTATOTA conformation can be assigned. Compared to the structure of 5a [13], which has tris(trimethylsilyl)silyl end groups, 14 features more aligned chain end segments.

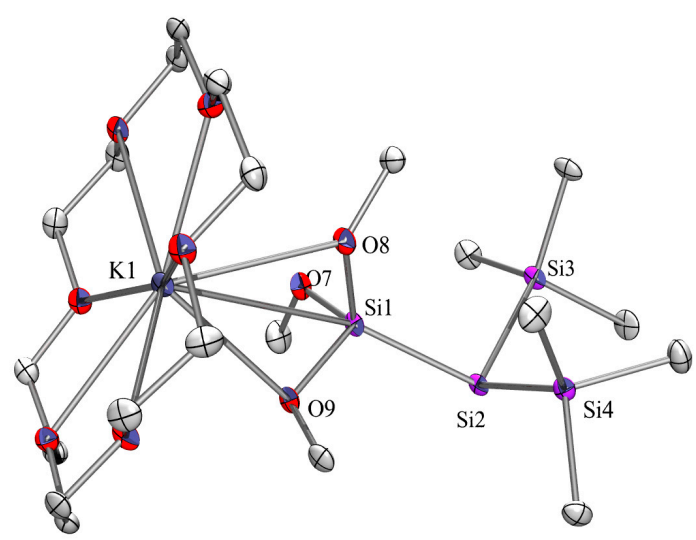

Figure 14. Crystal structure of 16a. Thermal ellipsoids are represented at the $30 \%$ level and hydrogen atoms have been omitted for clarity (bond lengths in $\AA$, angles in deg). K(1)-Si(1) 3.5694(19), Si(2)-Si(1) 2.313(2), Si(2)-Si(3) 2.3386(19), Si(2)-Si(4) 2.350(2), Si(3)-C(18) 1.883(5), Si(1)-O(7) 1.658(4), Si(1)-Si(2)-Si(4) 103.97(7), Si(3)-Si(2)-Si(4) 104.33(7), Si(2)-Si(1)-K(1) 158.14(7). 


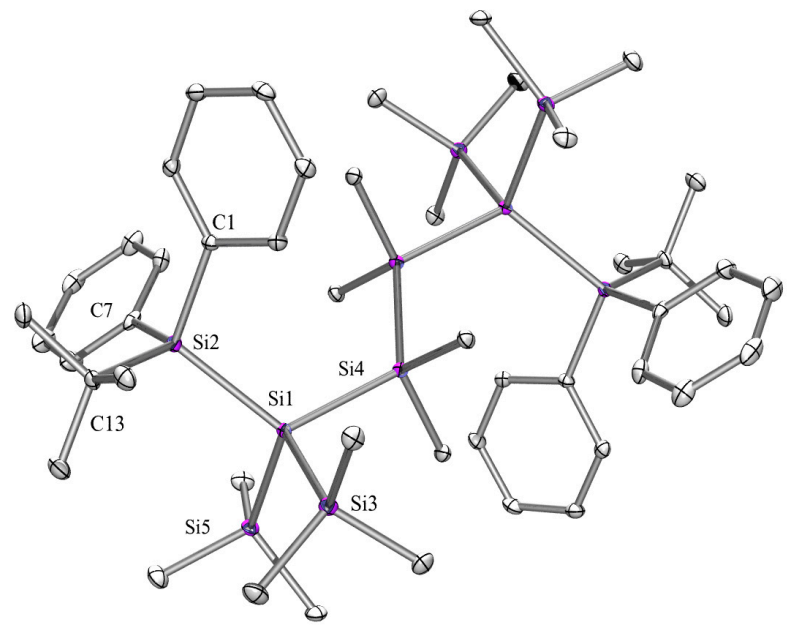

Figure 15. Crystal structure of $\mathbf{1 7}$. Thermal ellipsoids are represented at the $30 \%$ level and hydrogen atoms have been omitted for clarity (bond lengths in $\AA$, angles in deg). Si(1)-Si(5) 2.3726(9), Si(1)-Si(3) 2.3806(9), $\mathrm{Si}(1)-\mathrm{Si}(2)$ 2.4011(8), $\mathrm{Si}(1)-\mathrm{Si}(4)$ 2.4184(9), Si(2)-C(1) 1.887(2), Si(5)-Si(1)-Si(3) 105.73(3), $\mathrm{Si}(5)-\operatorname{Si}(1)-\operatorname{Si}(2)$ 107.99(3), Si(3)-Si(1)-Si(2) 114.99(3), Si(5)-Si(1)-Si(4) 107.83(3), Si(3)-Si(1)-Si(4) 100.65(3), Si(2)-Si(1)-Si(4) 118.74(3).

For 1,4-substituted cyclohexasilanes, a chair conformation with the large substituents in equatorial positions is typical [14,33,38-40]. However, 1,1,4,4,-tetrakis(trimethylsilyl)octamethylcyclohexasilane (26) crystallizing in the monoclinic space group $C 2 / \mathrm{c}$ is an exception as all four trimethylsilyl groups have the same steric demand allowing the system to adopt a twist conformation [34]. Changing two trimethylsilyl against triisopropylsilyl groups as in $\mathbf{2 1}$ led to two isomers whose crystals differ in shape so that they can be separated under the microscope. Both isomers crystallize in the space group C2/c. In the cis-isomer (21a) the two triisopropylsilyl groups occupy axial positions and the ring adopts a twist conformation whereas in $\mathbf{2 1} \mathbf{b}$ the substituents are both in equatorial position and the ring exhibits a chair conformation. A chair conformation was also reported for the related 1,4-bis(tert-butyldimethylsilyl)-1,4-bis(trimethylsilyl)octamethylcyclohexasilane with the two tert-butyldimethylsilyl groups in equatorial positions [33]. The cyclopentasilane ring in 22 exhibits an envelope conformation with one MePhSi unit on the flap and the phenyl groups in cis orientation.

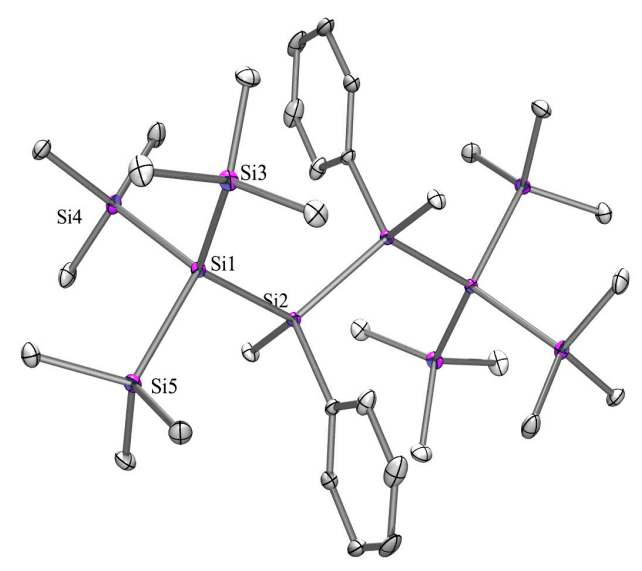

Figure 16. Crystal structure of 18. Thermal ellipsoids are represented at the $30 \%$ level and hydrogen atoms have been omitted for clarity (bond lengths in $\AA$, angles in deg). $\operatorname{Si}(1)-\operatorname{Si}(3) 2.3543(12), \operatorname{Si}(1)-\operatorname{Si}(4)$ 2.3592(12), Si(1)-Si(5) 2.3681(13), $\mathrm{Si}(1)-\mathrm{Si}(2)$ 2.3762(11), Si(2)-C(1) 1.886(3), Si(3)-Si(1)-Si(4) 106.64(4), Si(3)-Si(1)-Si(5) 108.04(4), Si(4)-Si(1)-Si(5) 105.41(5), Si(3)-Si(1)-Si(2) 118.47(4), Si(4)-Si(1)-Si(2) 111.25(4), $\operatorname{Si}(5)-\operatorname{Si}(1)-\operatorname{Si}(2) 106.28(4)$. 


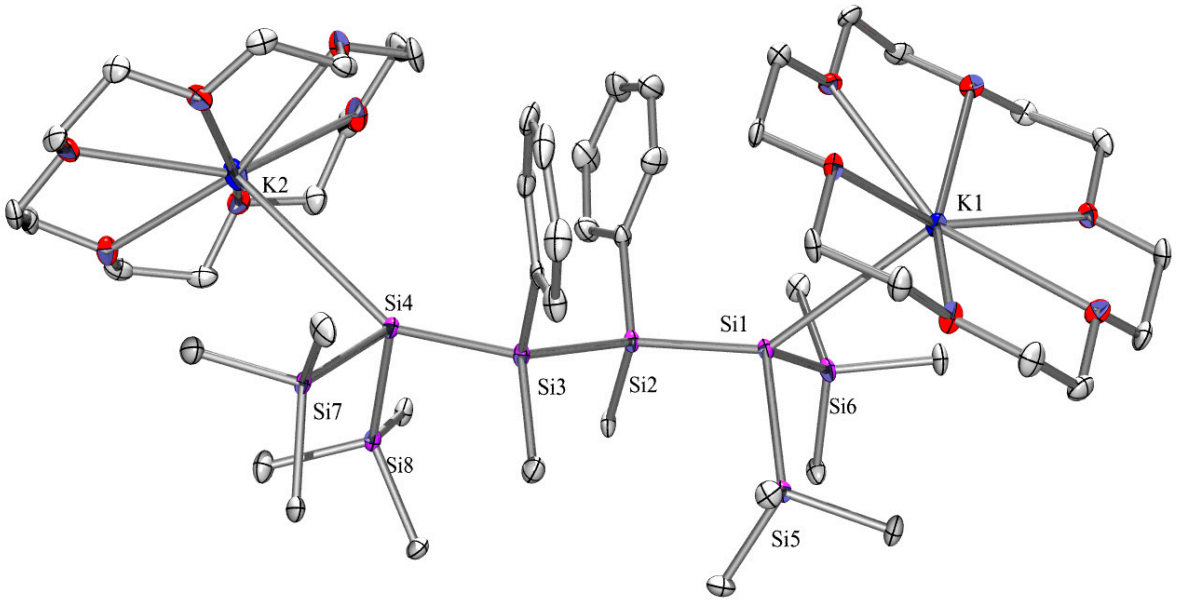

Figure 17. Crystal structure of 18a. Thermal ellipsoids are represented at the $30 \%$ level and hydrogen

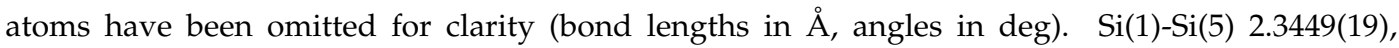
$\mathrm{Si}(1)-\mathrm{Si}(6)$ 2.350(2), Si(1)-Si(2) 2.360(2), Si(1)-K(1) 3.5079(19), Si(2)-C(1) 1.908(5), Si(2)-Si(3) 2.3734(17), Si(5)-Si(1)-Si(6) 99.17(7), Si(5)-Si(1)-Si(2) 106.41(7), Si(6)-Si(1)-Si(2) 98.25(7), Si(1)-Si(2)-Si(3) 117.41(7), Si(2)-Si(3)-Si(4) 115.99(7), Si(7)-Si(4)-Si(8) 96.39(7), Si(7)-Si(4)-Si(3) 99.23(8), Si(8)-Si(4)-Si(3) 104.83(7).

The two neopentasilanes 23 and 24 crystallize both in the monoclinic space group P2(1)/c. The structures are unexceptional with the Si-Si distances of $2.340 \AA$ in tetrakis(trimethylsilyl)silane [41] being elongated to $2.364-2.385 \AA$ in 24 and 2.360-2.383 $\AA$ in 23 .

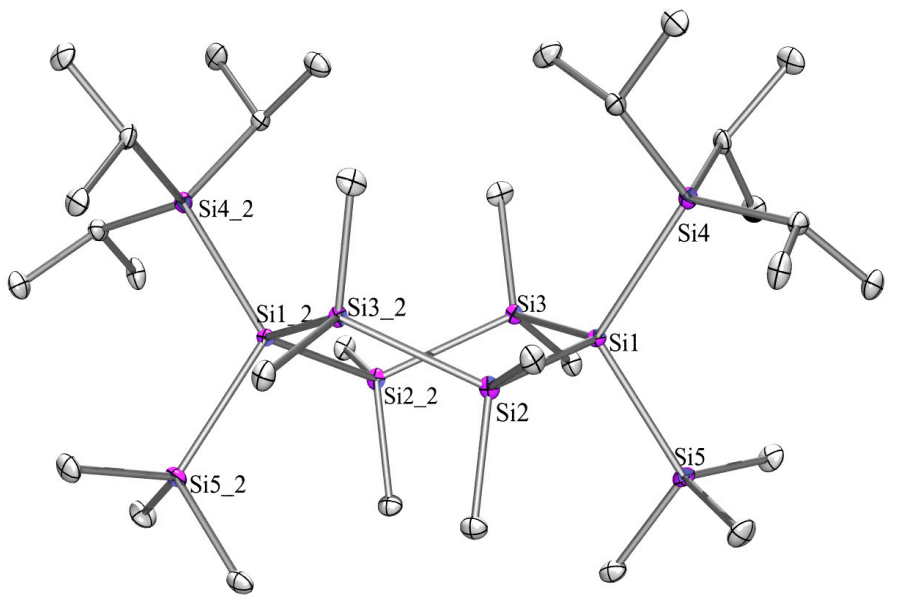

Figure 18. Crystal structure of 21a. Thermal ellipsoids are represented at the $30 \%$ level and hydrogen atoms have been omitted for clarity (bond lengths in $\AA$, angles in deg). $\operatorname{Si}(1)-\operatorname{Si}(5) 2.380(2)$, $\mathrm{Si}(1)-\mathrm{Si}(3)$ 2.381(2), Si(1)-Si(2) 2.382(2), Si(1)-Si(4) 2.408(2), Si(2)-C(2) 1.882(6), Si(5)-Si(1)-Si(3) 105.57(7), $\mathrm{Si}(5)-\mathrm{Si}(1)-\operatorname{Si}(2)$ 104.19(8), Si(3)-Si(1)-Si(2) 106.93(7), Si(5)-Si(1)-Si(4) 113.14(8), Si(3)-Si(1)-Si(4) 112.16(8), Si(2)-Si(1)-Si(4) 114.13(8).

The structures of the silyl anions 16a and 18a show both unexpected motives. While it is typical that the two potassium atoms of the silandiide 18a are coordinated by 18-crown- 6 ethers, a torsional angle of $48.0^{\circ}$ for K1-Si1-Si4-K2, which leads to a gauche conformation is rather unusual. For the few known structures of other crown ether potassium silyl dianions [33,42,43], the respective torsion angles for $\mathrm{K}-\mathrm{Si}-\mathrm{Si}-\mathrm{K}$ are ranging from $180.0^{\circ}$ to $147.7^{\circ}$ and therefore consequently show trans conformation. The only exception with a smaller angle was 1,1,5,5-tetrakis(trimethylsilyl) hexamethylpentasilanyl-1,5-dipotassium [42] with an ortho conformation $\left(84.8^{\circ}\right)$. 


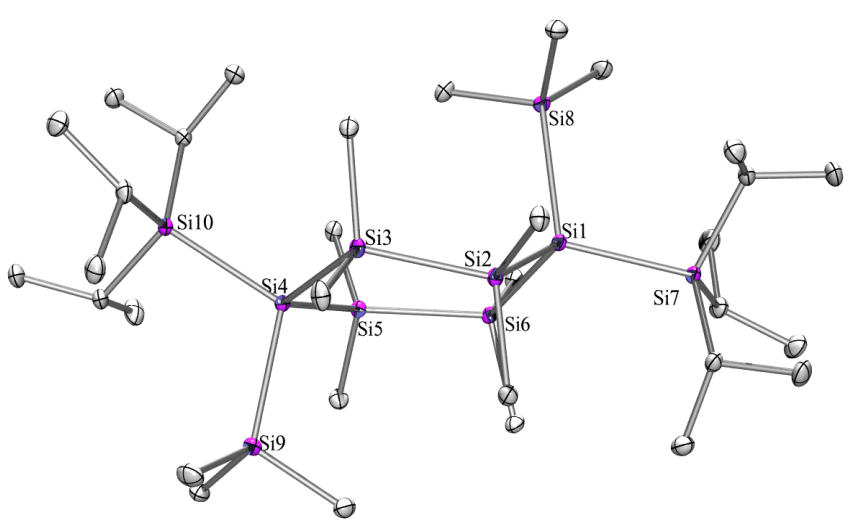

Figure 19. Crystal structure of 21b. Thermal ellipsoids are represented at the $30 \%$ level and hydrogen atoms have been omitted for clarity (bond lengths in $\AA$, angles in deg). $\operatorname{Si}(1)-\operatorname{Si}(2)$ 2.3613(7), Si(1)-Si(6) 2.3714(7), Si(1)-Si(8) 2.3734(8), Si(1)-Si(7) 2.4033(7), Si(2)-C(1) 1.8900(17), Si(2)-Si(3) 2.3603(7), Si(3)-Si(4) 2.3842(7), Si(4)-Si(5) 2.3899(8), Si(4)-Si(9) 2.3987(7), Si(4)-Si(10) 2.4169(8), Si(5)-Si(6) 2.3957(7), Si(2)-Si(1)-Si(6) 102.27(3), Si(2)-Si(1)-Si(8) 110.43(3), Si(6)-Si(1)-Si(8) 106.77(3), Si(2)-Si(1)-Si(7) 110.93(3), Si(6)-Si(1)-Si(7) 115.81(4), Si(8)-Si(1)-Si(7) 110.29(3), Si(3)-Si(2)-Si(1) 117.55(3), Si(2)-Si(3)-Si(4) 117.96(4), Si(3)-Si(4)-Si(5) 109.23(3), Si(3)-Si(4)-Si(9) 109.41(3), Si(5)-Si(4)-Si(9) 103.01(3), Si(3)-Si(4)-Si(10) 110.47(4), Si(5)-Si(4)-Si(10) 114.69(3), Si(9)-Si(4)-Si(10) 109.71(3), Si(4)-Si(5)-Si(6) 120.74(3), Si(1)-Si(6)-Si(5) 119.81(3).

Typically, the position of the potassium atom in solid state structures of potassium silanides is that of a tetrahedral substituent. Recently, some 18-crown-6 potassium oligosilanylsilatranes were published which show a distortion of the potassium atom in order to coordinate to both the anionic silicon atom and to an oxygen atom of remaining molecular scaffold [44]. In the silanides $\left(\mathrm{MeOMe}_{2} \mathrm{Si}\right)_{3} \mathrm{SiK}$ [45] and $\left(\mathrm{MeOCH}_{2} \mathrm{CH}_{2} \mathrm{OMe}_{2} \mathrm{Si}\right)_{3} \mathrm{SiK}$ [46], the potassium atom coordinates solely to the alkoxy groups. In 16a, a similar pattern can be observed where the potassium is coordinating exclusively to two oxygen atoms of the $(\mathrm{MeO})_{3} \mathrm{Si}$ substituent.

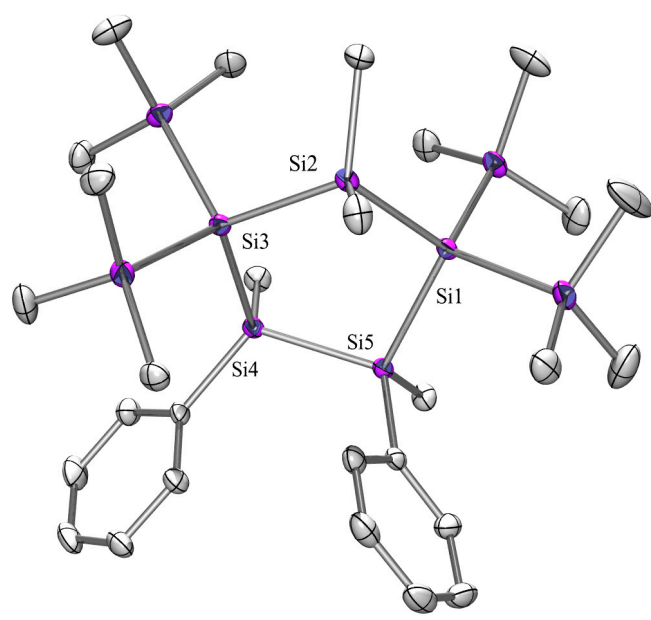

Figure 20. Crystal structure of 22. Thermal ellipsoids are represented at the $30 \%$ level and hydrogen

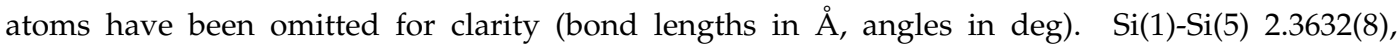
$\mathrm{Si}(1)-\operatorname{Si}(7)$ 2.3643(10), Si(1)-Si(2) 2.3684(10), Si(1)-Si(6) 2.3696(9), Si(2)-Si(3) 2.3796(10), Si(3)-Si(9) 2.3617(8), $\mathrm{Si}(3)-\mathrm{Si}(8)$ 2.3637(9), Si(3)-Si(4) 2.3667(9), Si(4)-Si(5) 2.3570(9), Si(5)-Si(1)-Si(7) 107.82(4), Si(5)-Si(1)-Si(2) 104.09(3), Si(7)-Si(1)-Si(2) 112.73(3), Si(5)-Si(1)-Si(6) 112.97(3), Si(7)-Si(1)-Si(6) 105.35(3), Si(2)-Si(1)-Si(6) 113.90(3), Si(1)-Si(2)-Si(3) 107.73(3), Si(9)-Si(3)-Si(8) 106.82(3), Si(9)-Si(3)-Si(4) 107.26(3), Si(8)-Si(3)-Si(4) 113.59(3), Si(9)-Si(3)-Si(2) 111.69(3), Si(8)-Si(3)-Si(2) 112.20(3), Si(4)-Si(3)-Si(2) 105.27(3), Si(5)-Si(4)-Si(3) 107.18(4), $\mathrm{Si}(4)-\operatorname{Si}(5)-\operatorname{Si}(1) 104.61(3)$. 


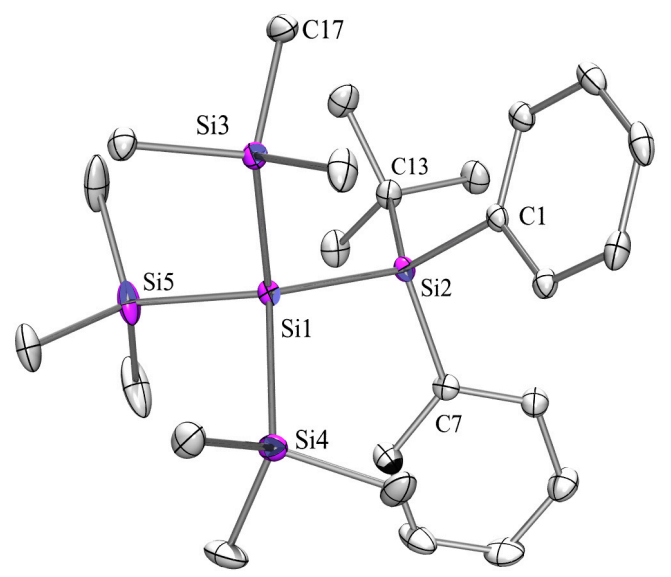

Figure 21. Crystal structure of 23. Thermal ellipsoids are represented at the $30 \%$ level and hydrogen atoms have been omitted for clarity (bond lengths in $\AA$, angles in deg). $\operatorname{Si}(1)-\operatorname{Si}(3) 2.3600(10), \operatorname{Si}(1)-\operatorname{Si}(5)$ 2.3654(10), Si(1)-Si(4) 2.3727(10), Si(1)-Si(2) 2.3827(10), Si(3)-Si(1)-Si(5) 107.02(4), Si(3)-Si(1)-Si(4) 105.31(4), Si(5)-Si(1)-Si(4) 103.48(4), Si(3)-Si(1)-Si(2) 108.01(3), Si(5)-Si(1)-Si(2) 119.85(3), Si(4)-Si(1)-Si(2) $112.18(3)$.

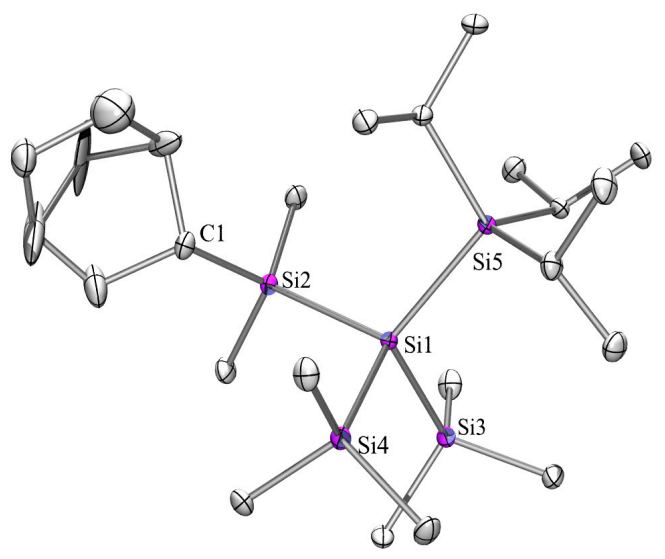

Figure 22. Crystal structure of 24. Thermal ellipsoids are represented at the $30 \%$ level and hydrogen atoms have been omitted for clarity (bond lengths in $\AA$, angles in deg). C(1)-C(2) 1.543(5), C(1)-Si(2) 1.914(3), Si(1)-Si(4) 2.3649(11), Si(4)-Si(1)-Si(3) 104.76(4), Si(4)-Si(1)-Si(2) 106.26(4), Si(3)-Si(1)-Si(2) 105.44(4).

\section{Experimental Section}

General Remarks: All reactions involving air-sensitive compounds were carried out under an atmosphere of dry nitrogen or argon using either Schlenk techniques or a glove box. Solvents were dried using a column solvent purification system [47]. All chemicals were obtained from different suppliers and were used without further purification. 1,2-Dichlorotetramethyldisilane [48,49], 1,3-dichlorohexamethyltrisilane [48,49], 1,4-dichlorooctamethyltetrasilane [48,49], tetrakis(trimethylsilyl) silane [50], isopropylbis(trimethylsilyl)silylpotassium [19], 2,5-bis(trimethylsilyl)dodecamethylhexasilane (3) [51], bis(trimethylsilyl)triisopropylsilylsilylpotassium [19], tris(trimethylsilyl)triisopropylsilyl silane [19], 2,2,5-tris(trimethylsilyl)undecamethylhexasilane [21], 2,2,6,6-tetrakis(trimethylsilyl)dodecameth ylheptasilane (25) [52], 2,2,5-tris(trimethylsilyl)undecamethylhexasilane [21], tris(trimethylsilyl)] trimethoxysilylsilane [53], 1,2-dimethyltetraphenyldisilane [54] and 1,1,4,4,-tetrakis(trimethylsilyl) octamethylcyclohexasilane (26) [33] were prepared according to literature procedures.

${ }^{1} \mathrm{H}-(300 \mathrm{MHz}),{ }^{13} \mathrm{C}-(75.4 \mathrm{MHz})$, and ${ }^{29} \mathrm{Si}-(59.3 \mathrm{MHz}) \mathrm{NMR}$ spectra were recorded on a Varian Unity INOVA 300 (Varian, Palo Alto, CA, USA). Samples for ${ }^{29} \mathrm{Si}$ spectra were either dissolved in 
deuterated solvents or in cases of reaction samples measured with a $\mathrm{D}_{2} \mathrm{O}$ capillary in order to provide an external lock frequency signal. To compensate for the low isotopic abundance of ${ }^{29} \mathrm{Si}$, the INEPT pulse sequence $[55,56]$ was used for the amplification of the signal. If not noted, otherwise the used solvent was $\mathrm{C}_{6} \mathrm{D}_{6}$ and samples were measured at rt. Elementary analysis was carried using a Heraeus VARIO ELEMENTAR EL apparatus (Hanau, Germany). UV spectra were measured on a Perkin Elmer Lambda 35 spectrometer (Perkin-Elmer Corp., Waltham, MA, USA) using spectroscopy grade pentane as solvent.

For X-ray structure analyses, the crystals were mounted onto the tip of glass fibers, and data collection was performed with a BRUKER-AXS SMART APEX CCD diffractometer (Bruker-AXS: Madison, WI, USA) using graphite-monochromated $\mathrm{Mo} \mathrm{K}_{\alpha}$ radiation $(0.71073 \AA)$. The data were reduced to $\mathrm{F}_{\mathrm{o}}{ }^{2}$ and corrected for absorption effects with SAINT [57] and SADABS [58,59], respectively. Structures were solved by direct methods and refined by full-matrix least-squares method (SHELXL97 and SHELX2013) [60]. All non-hydrogen atoms were refined with anisotropic displacement parameters. Hydrogen atoms were placed in calculated positions to correspond to standard bond lengths and angles. Crystallographic data (excluding structure factors) for the structures of compounds $\mathbf{9 , 1 4}$, 15, 16a, 17, 18, 18a, 21a, 21b, 22, 23 and 24 reported in this paper have been deposited with the Cambridge Crystallographic Data Center as supplementary publication no. CCDC 670864 (9), 975429 (14), 1486947 (15), 1486948 (16a), 1486950 (17), 1486951 (18), 1027155 (18a), 974732 (21a), 974731 (21b), 1486946 (22), 1486949 (23), and 1486945 (24). Copies of data can be obtained free of charge at: http://www.ccdc.cam.ac.uk/products/csd/request/. Figures of solid state molecular structures were generated using Ortep-3 as implemented in WINGX [61] and rendered with POV-Ray 3.6 [62].

Bis(trimethylsilyl)diisopropylsilane (1). A solution of isopropylbis(trimethylsilyl)silyl potassium (1.272 g, $2.431 \mathrm{mmol})$ in benzene $(20 \mathrm{~mL})$ was added dropwise at $0{ }^{\circ} \mathrm{C}$ to a solution of 2-chloropropane $(0.191 \mathrm{~g}$, 1.00 equiv) in benzene $(10 \mathrm{~mL})$. The reaction mixture remained colorless during the whole addition process and a white precipitate was formed. After $2 \mathrm{~h}$ at $0{ }^{\circ} \mathrm{C}$, the suspension was allowed to come to $\mathrm{rt}$ followed by an aqueous workup (diethyl ether). Compound $1(484 \mathrm{mg}, 74 \%)$ was obtained as a colorless liquid. ${ }^{1} \mathrm{H}-\mathrm{NMR}\left(\delta\right.$ in ppm): $1.18(\mathrm{~m}, 2 \mathrm{H}, \mathrm{CH}), 1.11\left(\mathrm{~d}, J=6.3 \mathrm{~Hz}, 12 \mathrm{H}, \mathrm{CH}_{3} \mathrm{CH}\right), 0.20$ (s, $\left.18 \mathrm{H}, \mathrm{Me}_{3} \mathrm{Si}\right) .{ }^{13} \mathrm{C}-\mathrm{NMR}\left(\delta\right.$ in ppm): $21.2\left(\mathrm{CH}_{3} \mathrm{CH}\right), 12.5(\mathrm{CH}), 1.4\left(\mathrm{Me}_{3} \mathrm{Si}\right) .{ }^{29} \mathrm{Si}-\mathrm{NMR}(\delta$ in ppm):

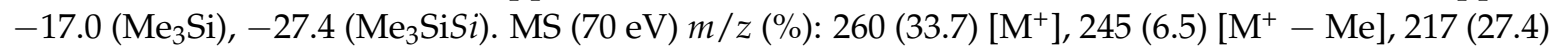
$\left[\mathrm{M}^{+}-\mathrm{CHMe}_{2}\right], 175(61.5)\left[\mathrm{M}^{+}-\left(\mathrm{CHMe}_{2}\right)_{2}\right], 73(100)\left[\mathrm{SiMe}_{3}{ }^{+}\right]$.

2,2,5,5-Tetraisopropyldecamethylhexasilane (2). Same procedure as described for $\mathbf{1}$ using 1,2-dichlorotetramethyldisilane $(54 \mathrm{mg}, 0.289 \mathrm{mmol})$ and for the preparation of the silanide: $\mathbf{1}(150 \mathrm{mg}$, $0.577 \mathrm{mmol}), 18$-crown-6 (152 mg, 1.00 equiv), and $\mathrm{KO}^{t} \mathrm{Bu}\left(65 \mathrm{mg}, 1.00\right.$ equiv) $\left({ }^{29} \mathrm{Si}-\mathrm{NMR}(\delta\right.$ in ppm, $\mathrm{D}_{2} \mathrm{O}$ capillary): $\left.\left.-14.4\left(\mathrm{Me}_{3} \mathrm{SiSiK}\right)\right),-54.0\left(\mathrm{Me}_{3} \mathrm{SiSiK}\right)\right)$. Compound $2(360 \mathrm{mg}, 90 \%)$ was obtained as a colorless crystalline solid. Mp: $199-206{ }^{\circ} \mathrm{C} .{ }^{1} \mathrm{H}-\mathrm{NMR}(\delta$ in ppm): $1.33(\mathrm{~m}, 4 \mathrm{H}, \mathrm{CH}), 1.18(\mathrm{~d}, J=7.8 \mathrm{~Hz}$, $\left.12 \mathrm{H}, \mathrm{CH}_{3}\right), 1.15\left(\mathrm{~d}, J=7.8 \mathrm{~Hz}, 12 \mathrm{H}, \mathrm{CH}_{3}\right), 0.47\left(\mathrm{~s}, 12 \mathrm{H}, \mathrm{Me}_{2} \mathrm{Si}\right), 0.28\left(\mathrm{~s}, 18 \mathrm{H}, \mathrm{Me}_{3} \mathrm{Si}\right) .{ }^{13} \mathrm{C}-\mathrm{NMR}(\delta$ in ppm): $21.7\left(\mathrm{CH}_{3}\right), 21.5\left(\mathrm{CH}_{3}\right), 12.0(\mathrm{CH}), 2.2\left(\mathrm{Me}_{3} \mathrm{Si}\right),-0.3\left(\mathrm{Me}_{2} \mathrm{Si}\right) .{ }^{29} \mathrm{Si}-\mathrm{NMR}\left(\delta\right.$ in ppm): $-15.7\left(\mathrm{Me}_{3} \mathrm{Si}\right),-18.3$ $\left(\mathrm{Me}_{3} \mathrm{SiSi}\right),-38.6\left(\mathrm{Me}_{2} \mathrm{Si}\right)$. MS (70 eV) m/z (\%): $490(4.0)\left[\mathrm{M}^{+}\right], 303(9.4)\left[\mathrm{M}^{+}-\mathrm{Si}_{2} \mathrm{Me}_{3}(\mathrm{CH})_{2}\left(\mathrm{CH}_{3}\right)_{4}\right]$, 245 (26.3) $\left[\mathrm{M}^{+}-\mathrm{Si}_{2} \mathrm{Me}_{4}(\mathrm{CH})_{3}\left(\mathrm{CH}_{3}\right)_{6}\right], 203$ (44.2) $\left[\mathrm{Si}_{4} \mathrm{Me}_{6} \mathrm{H}^{+}\right], 187$ (24.8) $\left[\mathrm{Si}_{4} \mathrm{Me}_{5}^{+}\right], 172$ (57.8) $\left[\mathrm{Si}_{4} \mathrm{Me}_{4}{ }^{+}\right]$, 73 (100) $\left[\mathrm{SiMe}_{3}{ }^{+}\right.$]. Anal. calcd. for $\mathrm{C}_{22} \mathrm{H}_{58} \mathrm{Si}_{6}$ (491.22): C 53.79, H 11.90. Found: C 53.42, H 11.85. UV absorption: $\lambda_{1}=209 \mathrm{~nm}\left(\varepsilon_{1}=1.7 \times 10^{4} \mathrm{M}^{-1} \cdot \mathrm{cm}^{-1}\right), \lambda_{2}=260 \mathrm{~nm}\left(\varepsilon_{2}=2.4 \times 10^{4} \mathrm{M}^{-1} \cdot \mathrm{cm}^{-1}\right)$, shoulder: $227 \mathrm{~nm}$.

2,5,8,11-Tetrakis(trimethylsilyl)docosamethyldodecasilane (5). To a solution of 1,2-dichlorotetramethyldisilane $(38 \mathrm{mg}, 0.202 \mathrm{mmol})$ in THF $(30 \mathrm{~mL})$ at $0{ }^{\circ} \mathrm{C}$ a solution of 5-trimethylsilyldodecamethylhexasilanyl2-potassium (4) (freshly prepared from: 2,5-bis(trimethylsilyl)dodecamethylhexasilane (3) (200 mg, $0.404 \mathrm{mmol}), \mathrm{KO}{ }^{t} \mathrm{Bu}(48 \mathrm{mg}, 0.424 \mathrm{mmol})$ in THF $(20 \mathrm{~mL}) ; 4:{ }^{29} \mathrm{Si}-\mathrm{NMR}\left(\delta\right.$ in ppm, $\mathrm{D}_{2} \mathrm{O}$ capillary): -6.8 ( $\left.\mathrm{Me}_{3} \mathrm{SiSiK}\right),-12.5$ ( $\left.\mathrm{Me}_{3} \mathrm{SiSiMe}\right),-26.5\left(\mathrm{Me}_{2} \mathrm{Si}\right),-35.7\left(\mathrm{Me}_{2} \mathrm{Si}\right),-88.1(\mathrm{MeSi}),-129.5(\mathrm{MeSiK})$ ) was added dropwise. After $14 \mathrm{~h}$ stirring at $\mathrm{rt}$ it was poured into a mixture of $\mathrm{H}_{2} \mathrm{SO}_{4}(0.5 \mathrm{M})$, diethylether, 
and ice. The layers were separated and the organic layer dried with $\mathrm{Na}_{2} \mathrm{SO}_{4}$. After removal of the solvent the two isomers of 5 were obtained as a colorless oil $(136 \mathrm{mg}, 70 \%) .{ }^{1} \mathrm{H}-\mathrm{NMR}(\delta$ in ppm, $\left.\mathrm{CDCl}_{3}\right): 0.31-0.23(\mathrm{~m}, 36 \mathrm{H}), 0.18(\mathrm{~s}, 36 \mathrm{H}), 0.16(\mathrm{~s}, 12 \mathrm{H}), 0.13(\mathrm{~s}, 18 \mathrm{H}) .{ }^{13} \mathrm{C}-\mathrm{NMR}\left(\delta\right.$ in ppm, $\left.\mathrm{CDCl}_{3}\right): 1.4$, 1.0, 0.4, $-1.0,-1.1,-1.1,-1.2,-1.2,-1.5,-1.6,-9.3,-11.4 .{ }^{29} \mathrm{Si}-\mathrm{NMR}\left(\delta\right.$ in ppm, $\left.\mathrm{CDCl}_{3}\right)$ : -11.6 $\left(\mathrm{Me}_{3} \mathrm{Si}\right),-11.7\left(\mathrm{Me}_{3} \mathrm{Si}\right),-11.8\left(\mathrm{Me}_{3} \mathrm{Si}\right),-11.8\left(\mathrm{Me}_{3} \mathrm{Si}\right),-33.1\left(\mathrm{Me}_{2} \mathrm{Si}\right),-33.7\left(\mathrm{Me}_{2} \mathrm{Si}\right),-33.7\left(\mathrm{Me}_{2} \mathrm{Si}\right)$, $-33.9\left(\mathrm{Me}_{2} \mathrm{Si}\right),-34.0\left(\mathrm{Me}_{2} \mathrm{Si}\right),-73.8(\mathrm{MeSi}),-74.3(\mathrm{MeSi}),-81.6(\mathrm{MeSi})$. UV absorption: $\lambda_{1}=218 \mathrm{~nm}$ $\left(\varepsilon_{1}=3.2 \times 10^{4} \mathrm{M}^{-1} \cdot \mathrm{cm}^{-1}\right), \lambda_{2}=268 \mathrm{~nm}\left(\varepsilon_{2}=1.6 \times 10^{4} \mathrm{M}^{-1} \cdot \mathrm{cm}^{-1}\right)$.

2,5,9,12-Tetrakis(trimethylsilyl)tetracosamethyltridecasilane (6). Same procedure as described for 5 using: $4(0.404 \mathrm{mmol})$ and 1,3-dichlorohexamethyltrisilane $(0.202 \mathrm{mmol}, 50 \mathrm{mg})$. Compound 6 was obtained as colorless oil (191 mg, 93\%, mixture of both isomers). ${ }^{1} \mathrm{H}-\mathrm{NMR}$ ( $\delta$ in ppm, $\left.\mathrm{CDCl}_{3}\right): 0.30-0.22(\mathrm{~m}, 36 \mathrm{H})$, $0.18(\mathrm{~s}, 36 \mathrm{H}), 0.16(\mathrm{~s}, 12 \mathrm{H}), 0.13(\mathrm{~s}, 24 \mathrm{H}) .{ }^{13} \mathrm{C}-\mathrm{NMR}\left(\delta\right.$ in ppm, $\left.\mathrm{CDCl}_{3}\right): 1.4,1.0,0.4,-1.1,-1.2,-1.3$, $-1.5,-1.6,-2.9,-9.4,-11.4 .{ }^{29} \mathrm{Si}-\mathrm{NMR}\left(\delta\right.$ in ppm, $\left.\mathrm{CDCl}_{3}\right):-11.7\left(\mathrm{Me}_{3} \mathrm{Si}\right),-11.8\left(\mathrm{Me}_{3} \mathrm{Si}\right),-11.9$ $\left(\mathrm{Me}_{3} \mathrm{Si}\right),-33.2\left(\mathrm{Me}_{2} \mathrm{Si}\right),-33.7\left(\mathrm{Me}_{2} \mathrm{Si}\right),-33.8\left(\mathrm{Me}_{2} \mathrm{Si}\right),-34.0\left(\mathrm{Me}_{2} \mathrm{Si}\right),-34.2\left(\mathrm{Me}_{2} \mathrm{Si}\right),-34.7\left(\mathrm{Me}_{2} \mathrm{Si}\right)$, $-36.3\left(\mathrm{Me}_{2} \mathrm{Si}\right),-36.4\left(\mathrm{Me}_{2} \mathrm{Si}\right),-74.4(\mathrm{MeSi}),-75.3(\mathrm{MeSi}),-81.6(\mathrm{MeSi}),-82.0(\mathrm{MeSi})$. UV absorption: $\lambda_{1}=212 \mathrm{~nm}\left(\varepsilon_{1}=2.7 \times 10^{4} \mathrm{M}^{-1} \cdot \mathrm{cm}^{-1}\right), \lambda_{2}=272 \mathrm{~nm}\left(\varepsilon_{2}=1.7 \times 10^{4} \mathrm{M}^{-1} \cdot \mathrm{cm}^{-1}\right)$, shoulder: $287 \mathrm{~nm}$.

2,5,10,13-Tetrakis(trimethylsilyl)hexacosamethyltetradecasilane (7). Same procedure as described for 5 using: 4 (0.404 mmol) and 1,4-dichlorooctamethyltetrasilane $(0.202 \mathrm{mmol}, 62 \mathrm{mg})$. Compound 7 was obtained as colorless oil (193 mg, $89 \%$, mixture of both isomers). ${ }^{1} \mathrm{H}-\mathrm{NMR}$ ( $\delta$ in ppm, $\mathrm{CDCl}_{3}$ ): $0.29-0.22$ $(\mathrm{m}, 36 \mathrm{H}), 0.18(\mathrm{~s}, 36 \mathrm{H}), 0.16(\mathrm{~s}, 12 \mathrm{H}), 0.13(\mathrm{~s}, 18 \mathrm{H}), 0.13(\mathrm{~s}, 12 \mathrm{H}) .{ }^{13} \mathrm{C}-\mathrm{NMR}\left(\delta\right.$ in ppm, $\left.\mathrm{CDCl}_{3}\right):$ 1.4, 1.0, $0.5,-1.1,-1.2,-1.3,-1.5,-1.6,-3.2,-3.2,-9.5,-11.4 .{ }^{29} \mathrm{Si}-\mathrm{NMR}\left(\delta\right.$ in ppm, $\left.\mathrm{CDCl}_{3}\right): 11.7$ $\left(\mathrm{Me}_{3} \mathrm{Si}\right),-11.8\left(\mathrm{Me}_{3} \mathrm{Si}\right),-11.9\left(\mathrm{Me}_{3} \mathrm{Si}\right),-33.7\left(\mathrm{Me}_{2} \mathrm{Si}\right),-33.8\left(\mathrm{Me}_{2} \mathrm{Si}\right),-34.0\left(\mathrm{Me}_{2} \mathrm{Si}\right),-36.2\left(\mathrm{Me}_{2} \mathrm{Si}\right)$, $-36.4\left(\mathrm{Me}_{2} \mathrm{Si}\right),-74.5(\mathrm{MeSi}),-75.5(\mathrm{MeSi}),-81.6(\mathrm{MeSi}),-82.0(\mathrm{MeSi}) . \mathrm{UV}$ absorption: $\lambda_{1}=222 \mathrm{~nm}$ $\left(\varepsilon_{1}=3.6 \times 10^{4} \mathrm{M}^{-1} \cdot \mathrm{cm}^{-1}\right), \lambda_{2}=285 \mathrm{~nm}\left(\varepsilon_{2}=2.4 \times 10^{4} \mathrm{M}^{-1} \cdot \mathrm{cm}^{-1}\right)$.

2,5-Bis(triisopropylsilyl)-2,5-bis(trimethylsilyl)decamethylhexasilan (9). $\quad$ To a solution of 1,2-dichlorotetramethyldisilane $(1.30 \mathrm{mmol}, 243 \mathrm{mg})$ in THF $(20 \mathrm{~mL})$ a solution of bis(trimethylsilyl) triisopropylsilylsilyl potassium $(2.47 \mathrm{mmol}, 916 \mathrm{mg})$ in THF $(10 \mathrm{~mL})$ was added dropwise. After $6 \mathrm{~h}$ same the work up procedure as for $\mathbf{5}$ was applied and crystallization from pentane/acetone yielded colorless crystalline 9 (908 mg, 91\%). Mp.: $221-225{ }^{\circ} \mathrm{C} .{ }^{1} \mathrm{H}-\mathrm{NMR}\left(\delta \mathrm{in} \mathrm{ppm}, \mathrm{CDCl}_{3}\right): 1.32$ (sept, $\left.6 \mathrm{H}, J=7 \mathrm{~Hz}, \mathrm{CH}\left(\mathrm{CH}_{3}\right)_{2}\right), 1.22\left(\mathrm{~d}, 36 \mathrm{H}, J=7 \mathrm{~Hz}, \mathrm{CH}\left(\mathrm{CH}_{3}\right)_{2}\right), 0.50\left(\mathrm{~s}, 12 \mathrm{H}, \mathrm{SiMe}_{2}\right), 0.33(\mathrm{~s}, 36 \mathrm{H}$, $\left.\mathrm{SiMe}_{3}\right) .{ }^{13} \mathrm{C}-\mathrm{NMR}\left(\delta\right.$ in ppm, $\left.\mathrm{CDCl}_{3}\right): 20.6\left(\mathrm{CH}\left(\mathrm{CH}_{3}\right)_{2}\right), 15.2\left(\mathrm{SiCH}\left(\mathrm{CH}_{3}\right)_{2}\right), 5.0\left(\mathrm{SiMe}_{3}\right), 3.1\left(\mathrm{SiMe}_{2}\right)$. ${ }^{29} \mathrm{Si}-\mathrm{NMR}\left(\delta\right.$ in ppm, $\left.\mathrm{CDCl}_{3}\right): 11.1\left({ }^{i} \mathrm{Pr}_{3} \mathrm{Si}\right),-9.1\left(\mathrm{Me}_{3} \mathrm{Si}\right),-24.5\left(\mathrm{Me}_{2} \mathrm{Si}\right),-120.3\left(\mathrm{Me}_{3} \mathrm{SiSi}\right)$. Anal. calcd. for $\mathrm{C}_{34} \mathrm{H}_{90} \mathrm{Si}_{10}$ (779.94): C 52.36, H 11.63. Found: C 52.09, H 11.58. UV Absorption: $\lambda_{1}=217 \mathrm{~nm}$ $\left(\varepsilon_{1}=2.7 \times 10^{4} \mathrm{M}^{-1} \cdot \mathrm{cm}^{-1}\right), \lambda_{2}=264 \mathrm{~nm}\left(\varepsilon_{2}=1.4 \times 10^{4} \mathrm{M}^{-1} \cdot \mathrm{cm}^{-1}\right)$, shoulder: $230 \mathrm{~nm}$.

2,5,8,11-Tetrakis(triisopropylsilyl)-2,5,8,11-tetrakis(trimethylsilyl)docosamethyl-dodeca-silane (11). Same procedure as described for 5 using: 2,5-bis(triisopropylsilyl)-5-tris(trimethylsilyl)decamethylhexasilyl-2-potassium (10) (freshly prepared from $9(200 \mathrm{mg}, 0.256 \mathrm{mmol})$ and $\mathrm{KO}^{t} \mathrm{Bu}(30 \mathrm{mg}, 0.269 \mathrm{mmol})$ in THF $(10 \mathrm{~mL})$ ) 10: ${ }^{1} \mathrm{H}-\mathrm{NMR}(\delta$ in ppm): $1.42(\mathrm{~m}, 36 \mathrm{H}), 1.34(\mathrm{~s}, 12 \mathrm{H}), 1.32(\mathrm{~s}, 6 \mathrm{H}), 0.83(\mathrm{~s}, 6 \mathrm{H}), 0.67(\mathrm{~s}, 6 \mathrm{H}), 0.55(\mathrm{~s}, 12 \mathrm{H})$, 0.53 (s, 18H). ${ }^{29} \mathrm{Si}-\mathrm{NMR}\left(\delta\right.$ in ppm): $22.4\left({ }^{i} \mathrm{Pr}_{3} \mathrm{SiSiK}\right), 13.5\left({ }^{i} \mathrm{Pr}_{3} \mathrm{SiSi}_{\mathrm{q}}\right),-7.2\left(\mathrm{Me}_{3} \mathrm{SiSiK}\right),-9.6\left(\mathrm{Me}_{3} \mathrm{Si}\right)$, $-14.2\left(\mathrm{Me}_{2} \mathrm{SiSiK}\right),-35.2\left(\mathrm{Me}_{2} \mathrm{Si}\right),-126.0\left(\mathrm{Si}_{\mathrm{q}}\right),-189.7(\mathrm{SiK})$.] and 1,2-dichlorotetramethyldisilane $(0.202 \mathrm{mmol}, 62 \mathrm{mg})$. After $3 \mathrm{~h}$ same work up procedure as for $\mathbf{5}$ yielded colorless crystalline $\mathbf{1 1}$ (220 mg, 87\%, mixture of both isomers). ${ }^{1} \mathrm{H}-\mathrm{NMR}(\delta$ in ppm): $1.10-1.37(\mathrm{~m}, 50 \mathrm{H}), 0.43(\mathrm{~s}, 36 \mathrm{H}), 0.33$ (s, 18H), 0.31 (s, 36H). ${ }^{29} \mathrm{Si}-\mathrm{NMR}\left(\delta\right.$ in ppm): $15.9\left({ }^{i} \operatorname{Pr}_{3} \mathrm{Si}\right), 15.9\left({ }^{i} \mathrm{Pr}_{3} \mathrm{Si}\right), 13.9\left({ }^{i} \operatorname{Pr}_{3} \mathrm{Si}\right), 13.5\left({ }^{i} \operatorname{Pr}_{3} \mathrm{Si}\right)$, -9.1 ( $\left.\mathrm{Me}_{3} \mathrm{Si}\right),-9.2\left(\mathrm{Me}_{3} \mathrm{Si}\right),-9.2\left(\mathrm{Me}_{3} \mathrm{Si}\right),-9.3\left(\mathrm{Me}_{3} \mathrm{Si}\right),-9.4\left(\mathrm{Me}_{3} \mathrm{Si}\right),-24.1\left(\mathrm{Me}_{2} \mathrm{Si}\right),-24.5\left(\mathrm{Me}_{2} \mathrm{Si}\right)$, -28.2 $\left(\mathrm{Me}_{2} \mathrm{Si}\right),-32.0\left(\mathrm{Me}_{2} \mathrm{Si}\right),-113.2\left(\mathrm{Si}_{\mathrm{q}}\right),-120.0\left(\mathrm{Si}_{\mathrm{q}}\right),-125.0\left(\mathrm{Si}_{\mathrm{q}}\right),-125.2\left(\mathrm{Si}_{\mathrm{q}}\right)$. UV absorption: $\lambda_{1}=216 \mathrm{~nm}\left(\varepsilon_{1}=3.1 \times 10^{4} \mathrm{M}^{-1} \cdot \mathrm{cm}^{-1}\right), \lambda_{2}=264 \mathrm{~nm}\left(\varepsilon_{2}=5.1 \times 10^{4} \mathrm{M}^{-1} \cdot \mathrm{cm}^{-1}\right)$, shoulder: $232 \mathrm{~nm}$. 
2,5,9,12-Tetrakis(triisopropylsilyl)-2,5,9,12-tetrakis(triisopropylsilyl)tetracosamethyl-tri-deca-silane (12). Same procedure as described for 11 using: 10 (0.152 mmol) and 1,3-dichlorhexamethyltrisilane (40 mg, $0.161 \mathrm{mmol})$. After $5 \mathrm{~h}$ same work up procedure as for 5 yielded 12 colorless oil $(271 \mathrm{mg}, 71 \%$, mixture of both isomers). ${ }^{1} \mathrm{H}-\mathrm{NMR}$ ( $\delta$ in ppm): $1.10-1.39(\mathrm{~m}, 50 \mathrm{H}), 0.48(\mathrm{~s}, 42 \mathrm{H}), 0.32(\mathrm{~s}, 18 \mathrm{H}), 0.30$ (s, 36H). ${ }^{29} \mathrm{Si}-\mathrm{NMR}\left(\delta\right.$ in ppm): $16.0\left({ }^{i} \operatorname{Pr}_{3} \mathrm{Si}\right), 14.1\left({ }^{i} \operatorname{Pr}_{3} \mathrm{Si}\right), 13.6\left({ }^{i} \operatorname{Pr}_{3} \mathrm{Si}\right),-9.1\left(\mathrm{Me}_{3} \mathrm{Si}\right),-9.2\left(\mathrm{Me}_{3} S i\right)$, -9.3 ( $\left.\mathrm{Me}_{3} \mathrm{Si}\right),-9.4\left(\mathrm{Me}_{3} \mathrm{Si}\right),-9.4\left(\mathrm{Me}_{3} \mathrm{Si}\right),-10.7\left(\mathrm{Me}_{3} \mathrm{Si}\right),-23.7\left(\mathrm{Me}_{2} \mathrm{Si}\right),-24.2\left(\mathrm{Me}_{2} \mathrm{Si}\right),-28.1\left(\mathrm{Me}_{2} \mathrm{Si}\right)$, -32.0 ( $\left.\mathrm{Me}_{2} \mathrm{Si}\right),-32,7\left(\mathrm{Me}_{2} \mathrm{Si}\right),-32.8\left(\mathrm{Me}_{2} \mathrm{Si}\right),-33.0\left(\mathrm{Me}_{2} \mathrm{Si}\right),-33.0\left(\mathrm{Me}_{2} \mathrm{Si}\right),-108.3\left(\mathrm{Si}_{q}\right),-119.7$ $\left(S i_{q}\right),-124.9\left(S i_{q}\right), 125.1\left(S i_{q}\right)$. UV absorption: $\lambda_{1}=219 \mathrm{~nm}\left(\varepsilon_{1}=2.8 \times 10^{4} \mathrm{M}^{-1} \cdot \mathrm{cm}^{-1}\right), \lambda_{2}=267 \mathrm{~nm}$ $\left(\varepsilon_{2}=4.6 \times 10^{4} \mathrm{M}^{-1} \cdot \mathrm{cm}^{-1}\right), \lambda_{3}=283 \mathrm{~nm}$ (shoulder), $\lambda_{4}=307 \mathrm{~nm}$ (shoulder).

2,5,10,13-Tetrakis(triisopropylsilyl)-2,5,10,13-tetrakis(triisopropylsilyl)hexacosamethyl-tetra-decasilane (13). Same procedure as described for 11 using: 10 (0.152 mmol) and 1,4-dichlorooctamethyltetrasilane $(51 \mathrm{mg}, 0.167 \mathrm{mmol})$. After $5 \mathrm{~h}$ same work up procedure as for 5 yielded 13 as a colorless oil $(211 \mathrm{mg}$, $81 \%$, mixture of both isomers). ${ }^{1} \mathrm{H}-\mathrm{NMR}$ ( $\delta$ in ppm): $1.12-1.37(\mathrm{~m}, 50 \mathrm{H}), 0.48(\mathrm{~s}, 48 \mathrm{H}), 0.32(\mathrm{~s}, 18 \mathrm{H}), 0.30$ (s, 36H). ${ }^{29} \mathrm{Si}-\mathrm{NMR}\left(\delta\right.$ in ppm): $16.9\left({ }^{i} \mathrm{Pr}_{3} \mathrm{Si}\right), 14.2\left({ }^{i} \operatorname{Pr}_{3} \mathrm{Si}\right), 14.1\left({ }^{i} \operatorname{Pr}_{3} \mathrm{Si}\right), 11.1\left({ }^{i} \operatorname{Pr}_{3} \mathrm{Si}\right),-9.1\left(\mathrm{Me}_{3} \mathrm{Si}\right),-9.2$ $\left(\mathrm{Me}_{3} \mathrm{Si}\right),-9.3\left(\mathrm{Me}_{3} \mathrm{Si}\right),-9.3\left(\mathrm{Me}_{3} \mathrm{Si}\right),-23.1\left(\mathrm{Me}_{2} \mathrm{Si}\right),-24.1\left(\mathrm{Me}_{2} \mathrm{Si}\right),-28.8\left(\mathrm{Me}_{2} \mathrm{Si}\right),-29.2\left(\mathrm{Me}_{2} \mathrm{Si}\right),-29.5$ $\left(\mathrm{Me}_{2} \mathrm{Si}\right),-29.6\left(\mathrm{Me}_{2} \mathrm{Si}\right),-31.3\left(\mathrm{Me}_{2} \mathrm{Si}\right),-32.0\left(\mathrm{Me}_{2} \mathrm{Si}\right),-104.6\left(\mathrm{Si}_{\mathrm{q}}\right),-106.9\left(\mathrm{Si}_{\mathrm{q}}\right),-119.3\left(\mathrm{Si}_{\mathrm{q}}\right),-119.4$ $\left(\mathrm{Si}_{\mathrm{q}}\right)$. UV absorption: $\lambda_{1}=220 \mathrm{~nm}\left(\varepsilon_{1}=2.9 \times 10^{4} \mathrm{M}^{-1} \cdot \mathrm{cm}^{-1}\right), \lambda_{2}=268 \mathrm{~nm}\left(\varepsilon_{2}=4.5 \times 10^{4} \mathrm{M}^{-1} \cdot \mathrm{cm}^{-1}\right)$, $\lambda_{3}=293 \mathrm{~nm}\left(\varepsilon_{2}=3.8 \times 10^{4} \mathrm{M}^{-1} \cdot \mathrm{cm}^{-1}\right), \lambda_{4}=311 \mathrm{~nm}$ (shoulder).

2,5,8,11-Tetrakis(trimethylsilyl)icosamethyldodecasilan (14). Same procedure as described for 5 using 2,5-bis(trimethylsilyl)undecamethylhexasilanyl-2-potassium (1.63 mmol) (prepared from: 2,2,5-tris (trimethylsilyl)undecamethylhexasilane (900 mg, $01.63 \mathrm{mmol}), \mathrm{KO}{ }^{t} \mathrm{Bu}(160 \mathrm{mg}, 1.71 \mathrm{mmol})$ in THF $(10 \mathrm{~mL}))$ and 1,2-dichlorotetramethyldisilane $(0.854 \mathrm{mmol}, 16 \mathrm{mg})$. After $5 \mathrm{~h}$ same work up procedure as for 5 yielded colorless crystalline $14(830 \mathrm{mg}, 95 \%)$ after recrystallization using pentane/acetone. ${ }^{1} \mathrm{H}-\mathrm{NMR}\left(\delta\right.$ in ppm, $\left.\mathrm{CDCl}_{3}\right): 0.46(\mathrm{~s}, 12 \mathrm{H}), 0.42(\mathrm{~s}, 12 \mathrm{H}), 0.35(\mathrm{~s}, 12 \mathrm{H}), 0.30(\mathrm{~s}, 36 \mathrm{H}), 0.28(\mathrm{~s}, 6 \mathrm{H}), 0.20$ $(\mathrm{s}, 36 \mathrm{H}) .{ }^{29} \mathrm{Si}-\mathrm{NMR}\left(\delta\right.$ in ppm, $\left.\mathrm{CDCl}_{3}\right):-9.2\left(\mathrm{Me}_{3} \mathrm{SiSiMe}\right),-11.7\left(\mathrm{Me}_{3} \mathrm{Si}\right),-28.2\left(\mathrm{SiMe}_{2}\right),-31.2\left(\mathrm{SiMe}_{2}\right)$, $-31.6\left(\mathrm{SiMe}_{2}\right),-80.6(\mathrm{SiMe}),-118.3\left(\left(\mathrm{Me}_{3} \mathrm{Si}\right)_{2} \mathrm{Si}\right)$. UV absorption: $\lambda=265 \mathrm{~nm}\left(\varepsilon=5.0 \times 10^{4} \mathrm{M}^{-1} \cdot \mathrm{cm}^{-1}\right)$.

2,5-Bis(trimethylsilyl)-2,5-bis(dimethyl-2'-exo-norbornylsilyl)decamethylhexasilane (15). A solution of tris(trimethylsilyl)silyl potassium (prepared from: tetrakis(trimethylsilyl)silane (2000 $\mathrm{mg}, 6.23 \mathrm{mmol})$ and $\mathrm{KO}^{t} \mathrm{Bu}(721 \mathrm{mg}, 6.42 \mathrm{mmol})$ in DME $(40 \mathrm{~mL})$ at $\left.60{ }^{\circ} \mathrm{C}\right)$ was added dropwise to a DME $(10 \mathrm{~mL})$ solution of dimethyl-2-exo-norbornylchlorosilane (1294 mg, $6.85 \mathrm{mmol})$. After $24 \mathrm{~h}$ same work up procedure as for 5 and crystallization out of acetone at rt. yielded colorless crystalline 2-(dimethyl-2'-exo-norbornylsilyl)-2-(trimethylsilyl)hexamethyltrisilane (15a) (1285 mg, 51\%). Mp.: 55-60 ${ }^{\circ} \mathrm{C} .{ }^{1} \mathrm{H}-\mathrm{NMR}\left(\delta\right.$ in ppm): $2.31(\mathrm{~s}, 2 \mathrm{H})$ 1.75-1.13 (m, 9H), $0.26\left(\mathrm{~s}, 27 \mathrm{H}, 3 \mathrm{SiMe}_{3}\right), 0.21\left(\mathrm{~s}, 3 \mathrm{H}, \mathrm{SiMe}_{2}\right)$, 0.16 (s, 3H, SiMe $)$ ). ${ }^{13} \mathrm{C}-\mathrm{NMR}$ ( $\delta$ in ppm): 38.8, 37.7, 37.1, 34.2, 33.5, 30.5, 28.8, $2.9\left(3 \mathrm{SiMe}_{3}\right),-0.3$ $\left(\mathrm{SiMe}_{2}\right)-0.5\left(\mathrm{SiMe}_{2}\right) .{ }^{29} \mathrm{Si}-\mathrm{NMR}\left(\delta\right.$ in ppm): $-5.6\left(\mathrm{SiMe}_{2}\right),-10.8\left(\mathrm{SiMe}_{3}\right),-136.3\left(\mathrm{Si}_{\mathrm{q}}\right)$. Anal. calcd. for $\mathrm{C}_{18} \mathrm{H}_{44} \mathrm{Si}_{5}$ (400.97): C 53.92, H 11.06. Found: C 53.61, H 10.96.

A solution of 2-dimethyl-2'-exo-norbornylsilylhexamethyltrisilyl-2-potassium (prepared from 15a $(1285 \mathrm{mg}, 3.20 \mathrm{mmol})$ and $\mathrm{KO}^{t} \mathrm{Bu}(377 \mathrm{mg}, 3.36 \mathrm{mmol})$ in THF (40 mL) at rt.) is slowly added to a solution of 1,2-dichlorotetramethylsilane (300 mg, $1.6 \mathrm{mmol})$ in THF (10 mL). After $24 \mathrm{~h}$ same work up procedure as for 5 and crystallization out of acetone at $-20^{\circ} \mathrm{C}$ yielded colorless crystalline $15(1010 \mathrm{mg}$, 82\%). Mp: $125-127{ }^{\circ} \mathrm{C} .{ }^{1} \mathrm{H}-\mathrm{NMR}$ ( $\delta$ in ppm): 2.50 (s, 4H) 1.62-0.90 (m, 18H), 0.57 (s, 12H, SiMe $), 0.34$ and 0.33 (each s, $18 \mathrm{H}, \mathrm{SiMe}_{3}$ ), 0.31 and 0.24 (each s, 6H, SiMe 2$) .{ }^{13} \mathrm{C}-\mathrm{NMR}$ ( $\delta$ in ppm): 39.9, 38.9, 37.1, 34.1, 33.8, 32.3, 28.8, $3.8\left(\mathrm{SiMe}_{3}\right), 1.8\left(2 \mathrm{SiMe}_{3}\right), 0.4$ and $0.6\left(\mathrm{SiMe}_{2}\right) .{ }^{29} \mathrm{Si}-\mathrm{NMR}(\delta$ in ppm $):-5.2\left(\mathrm{SiMe}_{2}\right)$, -9.7 (2 $\left.\mathrm{SiMe}_{3}\right),-29.1$ (2 $\left.\mathrm{SiMe}_{2}\right),-127.4\left(\mathrm{Si}_{\mathrm{q}}\right)$. Anal. calcd. for $\mathrm{C}_{34} \mathrm{H}_{82} \mathrm{Si}_{10}$ (771.88): C 52.91, H 10.71. Found: C 52.41, H 10.59. UV absorption: $\lambda=258 \mathrm{~nm}\left(\varepsilon=7.1 \times 10^{4} \mathrm{M}^{-1} \cdot \mathrm{cm}^{-1}\right)$.

2,5-Bis(trimethoxysilyl)-2,5-bis(trimethylsilyl)decamethylhexasilane (16). Tris(trimethyl-silyl)]-trimethoxysilylsilane (100 mg, $0.272 \mathrm{mmol})$ and $\mathrm{KO}^{t} \mathrm{Bu}(32 \mathrm{mg}, 0.285 \mathrm{mmol})$ were dissolved in THF (2 mL). 
After NMR spectroscopy confirmed complete formation of the silanide 16a the solution was added dropwise to an ice cooled solution of 1,2-dichlorotetramethyldisilane ( $27 \mathrm{mg}, 0.142 \mathrm{mmol}$ ) in toluene $(5 \mathrm{~mL})$. After $2 \mathrm{~h}$ the solvent was removed and the residue crystallized from a mixture of diethylether and acetonitrile 2:1. Colorless crystals of $16(67 \mathrm{mg}, 69 \%)$ were obtained. Mp: $134-138{ }^{\circ} \mathrm{C} .{ }^{1} \mathrm{H}-\mathrm{NMR}$ ( $\delta$ in ppm): $3.48\left(\mathrm{~s}, 18 \mathrm{H}, \mathrm{OMe}_{3}\right), 0.71\left(\mathrm{~s}, 12 \mathrm{H}, \mathrm{SiMe}_{2}\right), 0.46\left(\mathrm{~s}, 36 \mathrm{H}, \mathrm{SiMe}_{3}\right) .{ }^{13} \mathrm{C}-\mathrm{NMR}(\delta$ in ppm): 50.3 $(\mathrm{OMe}), 3.3\left(\mathrm{SiMe}_{3}\right), 0.4\left(\mathrm{SiMe}_{2}\right) .{ }^{29} \mathrm{Si}-\mathrm{NMR}\left(\delta\right.$ in ppm): -9.2 $\left(\mathrm{SiMe}_{3}\right),-30.5\left(\mathrm{SiMe}_{2}\right),-32.7\left(\mathrm{Si}(\mathrm{OMe})_{3}\right)$, -135.7 ( $\mathrm{SiMe}_{3}$ ). Anal. calcd. for $\mathrm{C}_{22} \mathrm{H}_{66} \mathrm{O}_{6} \mathrm{Si}_{10}$ (706.25): C 37.34, H 9.40. Found: C 38.48, H 9.00. UV absorption: $\lambda=253 \mathrm{~nm}\left(\varepsilon=8.4 \times 10^{4} \mathrm{M}^{-1} \cdot \mathrm{cm}^{-1}\right)$ in n-hexane.

For the characterization of silanide 16a its formation was undertaken in the presence of 18-crown-6: A mixture of $50 \mathrm{mg}(0.135 \mathrm{mmol}, 1 \mathrm{eq})$ of tris(trimethyl-silyl)]-trimethoxy-silylsilane, KOtBu (16 mg, $0.142 \mathrm{mmol})$ and 18 -crown-6 $(38 \mathrm{mg}, 0.098 \mathrm{mmol})$ was dissolved in $\mathrm{C}_{6} \mathrm{D}_{6}(1 \mathrm{~mL})$ and left for $14 \mathrm{~h}$. After NMR spectroscopy confirmed formation of methoxysilylpotassium in a pale beige solution, $\mathrm{C}_{6} \mathrm{D}_{6}$ was removed in vacuum after which the residue was dissolved in diethylether. Very sensitive pale beige crystals of 16a were obtained on the walls of the vial. Yield: $(80 \mathrm{mg}, 100 \%) .{ }^{1} \mathrm{H}-\mathrm{NMR}$ (d in ppm: 3.74 $\left(\mathrm{s}, 9 \mathrm{H}, \mathrm{OCH}_{3}\right), 3.24\left(\mathrm{~s}, 24 \mathrm{H}, \mathrm{CH}_{2} \mathrm{O}\right), 0.68\left(\mathrm{~s}, 18 \mathrm{H}, \mathrm{Si}\left(\mathrm{CH}_{3}\right)_{3}\right) .{ }^{13} \mathrm{C}-\mathrm{NMR}\left(\mathrm{d}\right.$ in ppm): $70.1\left(\mathrm{CH}_{2} \mathrm{O}\right), 50.1$

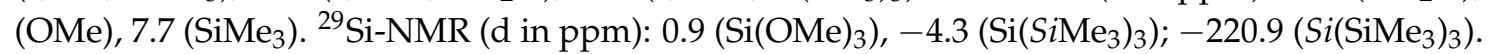

2,5-Bis(tert-butyldiphenylsilyl)-2,5-bis(trimethylsilyl)decamethylhexasilane (17). Compound 23 (300 mg, $0.616 \mathrm{mmol})$ and $\mathrm{KO}^{t} \mathrm{Bu}(71 \mathrm{mg}, 0.635 \mathrm{mmol})$ were dissolved in THF $(3 \mathrm{~mL})$. After NMR spectroscopy confirmed complete formation the solvent was removed, the residue solved in toluene $(3 \mathrm{~mL})$ and added dropwise over 5 minutes to a solution of 1,2-dichlorotetramethyldisilane (60 mg, $0.323 \mathrm{mmol})$ in toluene $(2 \mathrm{~mL})$. After $3 \mathrm{~h}$ same work up procedure as for 5 yielded after recrystallization from pentane/acetone 2:1 colorless crystalline $25(210 \mathrm{mg}, 72 \%)$. Mp: $200-204{ }^{\circ} \mathrm{C} .{ }^{1} \mathrm{H}-\mathrm{NMR}(\delta$ in ppm $\left.\mathrm{CDCl}_{3}\right)$ : $7.66(\mathrm{~m}, 8 \mathrm{H}, \mathrm{Ph}), 7.35(\mathrm{~m}, 12 \mathrm{H}, \mathrm{Ph}), 1.09\left(\mathrm{~s}, 18 \mathrm{H},{ }^{t} \mathrm{Bu}\right), 0.47\left(\mathrm{~s}, 12 \mathrm{H}, \mathrm{SiMe}_{2}\right), 0.11\left(\mathrm{~s}, 36 \mathrm{H}, \mathrm{SiMe}_{3}\right)$. ${ }^{13} \mathrm{C}-\mathrm{NMR}\left(\delta\right.$ in ppm CDCl 3 ): 137.38, 137.17, 128.81, 127.16, $29.77\left({ }^{t} \mathrm{Bu}\right), 20.39\left({ }^{t} \mathrm{Bu}\right), 4.54\left(\mathrm{SiMe}_{3}\right), 2.84$ $\left(\mathrm{SiMe}_{2}\right) .{ }^{29} \mathrm{Si}-\mathrm{NMR}\left(\delta\right.$ in ppm $\left.\mathrm{CDCl}_{3}\right): 5.4\left(\mathrm{SiPh}_{2}{ }^{t} \mathrm{Bu}\right),-8.7\left(\mathrm{Me}_{3} \mathrm{Si}\right),-23.8\left(\mathrm{Me}_{2} \mathrm{Si}\right),-121.9\left(\mathrm{Si}_{\mathrm{q}}\right)$. Anal. calcd. for $\mathrm{C}_{48} \mathrm{H}_{86} \mathrm{O}_{6} \mathrm{Si}_{10}$ (944.07): C 61.07, H 9.18. Found: C 60.94, H 8.93. UV absorption: $\lambda=240 \mathrm{~nm}$ $\left(\varepsilon=3.2 \times 10^{4} \mathrm{M}^{-1} \cdot \mathrm{cm}^{-1}\right), \lambda=270 \mathrm{~nm}\left(\varepsilon=6.8 \times 10^{4} \mathrm{M}^{-1} \cdot \mathrm{cm}^{-1}\right)$ in diethylether.

2,2,5,5-Tetrakis(trimethylsilyl)-3,4-diphenyloctamethylhexasilane (18). $\quad$ To a solution of 1,2-dimethyltetraphenyldisilane $(775 \mathrm{mg}, 1.9 \mathrm{mmol})$ in $\mathrm{CH}_{2} \mathrm{Cl}_{2}(10 \mathrm{~mL})$ triflic acid $(604 \mathrm{mg}$, $3.9 \mathrm{mmol}$ ) is added slowly. After $12 \mathrm{~h}$ the reaction is complete (controlled by ${ }^{29} \mathrm{Si}-\mathrm{NMR}$ ), the solvent is removed and the white precipitate is suspended in toluene $(10 \mathrm{~mL})$. A solution of tris(trimethylsilyl)silyl potassium (prepared from tetrakis(trimethylsilyl)silane (1192 mg, $3.7 \mathrm{mmol}$ ), $\mathrm{KO}^{t} \mathrm{Bu}(3.9 \mathrm{mmol})$, and 18-crown-6 $(3.9 \mathrm{mmol})$ in toluene $\left.(10 \mathrm{~mL})\right)$ is added slowly. After $24 \mathrm{~h}$ same work up procedure as for 5 and crystallization out of acetone at $-20^{\circ} \mathrm{C}$ yielded colorless crystalline $18(1.43 \mathrm{~g}, 98 \%)$. Mp: $271-273{ }^{\circ} \mathrm{C} .{ }^{1} \mathrm{H}-\mathrm{NMR}\left(\delta\right.$ in ppm): $6.70(\mathrm{~m}, 10 \mathrm{H}), 0.39\left(\mathrm{~s}, 6 \mathrm{H},(\mathrm{SiMe})_{2}\right), 0.30$ $\left(\mathrm{s}, 54 \mathrm{H},\left(\mathrm{SiMe}_{3}\right)_{6}\right) .{ }^{13} \mathrm{C}-\mathrm{NMR}\left(\delta\right.$ in ppm, $\left.\mathrm{CDCl}_{3}\right): 138.8,135.7,128.2,127.9,3.1\left(\mathrm{SiMe}_{3}\right),-0.6(\mathrm{SiMePh})$. ${ }^{29} \mathrm{Si}-\mathrm{NMR}\left(\delta\right.$ in ppm): $-9.5\left(\mathrm{SiMe}_{3}\right),-30.3(\mathrm{SiMePh}),-124.2\left(\mathrm{Si}_{q}\right)$. Anal. calcd. for $\mathrm{C}_{32} \mathrm{H}_{70} \mathrm{Si}_{10}(735.76)$ : C 52.24, H 9.59. Found: C 49.73, H 9.36. UV absorption: $\lambda=262 \mathrm{~nm}\left(\varepsilon=2.4 \times 10^{4} \mathrm{M}^{-1} \cdot \mathrm{cm}^{-1}\right)$.

1,5-Bis(pentamethyldisilanyl)-1,1,5,5-tetrakis(trimethylsilyl)hexamethylpentasilane (19). To a solution of pentamethyldisilanylchloride $(260 \mathrm{mg}, 1.559 \mathrm{mmol})$ in benzene $(4 \mathrm{~mL})$ a solution of 2,6-bis (trimethylsilyl)dodecamethylheptasilyl 2,6-dipotassium (prepared from: 2,2,6,6-tetrakis(trimethylsilyl) dodecamethylheptasilane ( $390 \mathrm{mg}, 0.773 \mathrm{mmol}), 18$-crown 6 (413 mg, 2.02 equiv) and $\mathrm{KO}^{t} \mathrm{Bu}(175 \mathrm{mg}$, 2.02 equiv) in benzene $(5 \mathrm{~mL})$ ) was added dropwise over a period of $10 \mathrm{~min}$. After $2 \mathrm{~h}$ same work up procedure as for 5 and colorless waxy $19(528 \mathrm{mg}, 87 \%)$ was obtained. Mp: $85-95{ }^{\circ} \mathrm{C} .{ }^{1} \mathrm{H}-\mathrm{NMR}$ ( $\delta$ in ppm): $0.54(\mathrm{~s}, 12 \mathrm{H}+6 \mathrm{H}), 0.40(\mathrm{~s}, 12 \mathrm{H}), 0.36(\mathrm{~s}, 36 \mathrm{H}), 0.22(\mathrm{~s}, 18 \mathrm{H}) .{ }^{13} \mathrm{C}-\mathrm{NMR}(\delta$ in ppm): 4.0, 1.6, -0.3 , $-0.4,-1.6$. ${ }^{29} \mathrm{Si}-\mathrm{NMR}\left(\delta\right.$ in ppm): $-9.6,-14.4,-29.7,-36.7,-39.0,-122.5$. Anal. calcd. for $\mathrm{C}_{28} \mathrm{H}_{84} \mathrm{Si}_{13}$ (786.083): C 42.78, H 10.77. Found: C 41.23, H 9.99. UV absorption: $\lambda_{1}=226 \mathrm{~nm}\left(\varepsilon_{1}=2.1 \times 10^{4} \mathrm{M}^{-1} \cdot \mathrm{cm}^{-1}\right)$, $\lambda_{2}=230 \mathrm{~nm}\left(\varepsilon_{2}=1.9 \times 10^{4} \mathrm{M}^{-1} \cdot \mathrm{cm}^{-1}\right), \lambda_{3}=273 \mathrm{~nm}\left(\varepsilon_{2}=3.6 \times 10^{4} \mathrm{M}^{-1} \cdot \mathrm{cm}^{-1}\right)$. 
2,2,8,8-Tetrakis(trimethylsilyl)hexadecamethylnonasilane (20). A solution of 19 (210 mg, $0.272 \mathrm{mmol})$ and $\mathrm{Al}(\mathrm{Fe}) \mathrm{Cl}_{3}(20 \mathrm{mg})$ in cyclohexane $(3 \mathrm{~mL})$ was heated to reflux. After $16 \mathrm{~h}$ the reaction was complete (controlled by ${ }^{29} \mathrm{Si}-\mathrm{NMR}$ ) and acetone $(10 \mathrm{~mL})$ was added. The precipitate was removed by centrifugation, the solvent removed and the residue crystallized by using acetone. Colorless crystalline of 20 was obtained $(136 \mathrm{mg}, 65 \%)$. Mp: $182-186{ }^{\circ} \mathrm{C} .{ }^{1} \mathrm{H}-\mathrm{NMR}(\delta$ in ppm): $0.49(\mathrm{~s}, 12 \mathrm{H}), 0.43(\mathrm{~s}, 12 \mathrm{H})$, $0.39(\mathrm{~s}, 6 \mathrm{H}), 0.33(\mathrm{~s}, 54 \mathrm{H}) .{ }^{13} \mathrm{C}-\mathrm{NMR}\left(\delta\right.$ in ppm): $3.4,0.9,-2.7,-3.3 .{ }^{29} \mathrm{Si}-\mathrm{NMR}(\delta$ in ppm): $-9.8,-31.9$, -35.3, -36.6, -129.1. Anal. calcd. for $\mathrm{C}_{28} \mathrm{H}_{84} \mathrm{Si}_{13}$ (786.083): C 42.78, H 10.77. Found: C 41.23, H 9.99. UV Absorption: $\lambda_{1}=288 \mathrm{~nm}\left(\varepsilon_{1}=4.0 \times 10^{4}\left(\mathrm{M}^{-1} \cdot \mathrm{cm}^{-1}\right)\right), \lambda_{2}=271 \mathrm{~nm}\left(\varepsilon_{2}=2.7 \times 10^{4} \mathrm{M}^{-1} \cdot \mathrm{cm}^{-1}\right)$, $\lambda_{3}=246 \mathrm{~nm}\left(\varepsilon_{3}=1.7 \times 10^{4} \mathrm{M}^{-1} \cdot \mathrm{cm}^{-1}\right)$.

1,4-Bis(triisopropylsilyl)-1,4-bis(trimethylsilyl)octamethylcyclohexasilane (21). A dark red solution of the dianion (prepared from: 9 (215 g, $0.276 \mathrm{mmol}), \mathrm{KO}^{t} \mathrm{Bu}(68 \mathrm{mg}, 0.606 \mathrm{mmol}), 18$-crown-6 (160 mg, $0.606 \mathrm{mmol})$ in benzene $(10 \mathrm{~mL})$ ) diluted with THF $(3 \mathrm{~mL})$ was added dropwise to a solution of 1,2-dichlorotetramethyldisilane ( $48 \mathrm{mg}, 0.256 \mathrm{mmol}$ ) in THF ( $5 \mathrm{~mL}$ ). After $24 \mathrm{~h}$ same work up procedure as for 5 yielded colorless crystalline $21\left(80 \mathrm{mg}\right.$, 39\%) after recrystallization with $\mathrm{Et}_{2} \mathrm{O}$. Anal. calcd. for $\mathrm{C}_{32} \mathrm{H}_{84} \mathrm{Si}_{10}$ (749.86): C 51.25, H 11.29. Found: C 51.01, H 11.03. The crystals were so large that they could be separated manually and so it was possible to characterize both isomers.

Cis-1,4-bis(triisopropylsilyl)-1,4-bis(trimethylsilyl)cyclohexasilane (21a): Mp: $229-231{ }^{\circ} \mathrm{C} .{ }^{1} \mathrm{H}-\mathrm{NMR}(\delta$ in ppm): 1.35 (sept, 6H, Si $\left.(\mathrm{CH})\left(\mathrm{CH}_{3}\right)_{2}\right), 1.20$ (d, J = 7.2 Hz, 36H, $\left.\mathrm{Si}(\mathrm{CH})\left(\mathrm{CH}_{3}\right)_{2}\right), 0.48\left(\mathrm{~s}, 12 \mathrm{H}, \mathrm{SiMe}_{3}\right)$, $0.47\left(\mathrm{~s}, 12 \mathrm{H}, \mathrm{SiMe}_{3}\right), 0.40\left(\mathrm{~s}, 18 \mathrm{H}, \mathrm{SiMe}_{3}\right) .{ }^{13} \mathrm{C}-\mathrm{NMR}\left(\delta\right.$ in ppm): $20.6\left({ }^{i} \mathrm{Pr}\right), 14.6\left({ }^{i} \mathrm{Pr}\right), 5.4\left(\mathrm{SiMe}_{3}\right), 1.2$ $\left(\mathrm{SiMe}_{3}\right), 0.9\left(\mathrm{SiMe}_{2}\right) .{ }^{29} \mathrm{Si}-\mathrm{NMR}\left(\delta\right.$ in ppm): $22.8\left(\mathrm{Si}^{-}{ }^{-} \mathrm{Pr}_{3}\right),-8.7\left(\mathrm{SiMe}_{3}\right),-37.0\left(\mathrm{SiMe}_{2}\right),-128.9\left(\mathrm{Si}_{\mathrm{q}}\right) . \mathrm{UV}$ absorption: $\lambda_{1}=251 \mathrm{~nm}\left(\varepsilon_{1}=6.1 \times 10^{3} \mathrm{M}^{-1} \cdot \mathrm{cm}^{-1}\right)$, shoulder: $276 \mathrm{~nm}\left(\varepsilon=8.3 \times 10^{2} \mathrm{M}^{-1} \cdot \mathrm{cm}^{-1}\right)$.

Trans-1,4-bis(triisopropylsilyl)-1,4-bis(trimethylsilyl)cyclohexasilane (21b): Mp: $240-242{ }^{\circ} \mathrm{C} .{ }^{1} \mathrm{H}-\mathrm{NMR}$ ( $\delta$ in ppm): 1.40 (sept, 6H, Si $\left.(\mathrm{CH})\left(\mathrm{CH}_{3}\right)_{2}\right), 1.21\left(\mathrm{~d}, J=7.2 \mathrm{~Hz}, 36 \mathrm{H}, \mathrm{Si}(\mathrm{CH})\left(\mathrm{CH}_{3}\right)_{2}\right), 0.53(\mathrm{~s}, 12 \mathrm{H}$, $\left.\mathrm{SiMe}_{2}\right), 0.46$ (s, 12H, SiMe $), 0.40$ (s, 18H, SiMe $) .{ }^{13} \mathrm{C}-\mathrm{NMR}$ ( $\delta$ in ppm): $20.5\left({ }^{i} \mathrm{Pr}\right), 14.8\left({ }^{i} \mathrm{Pr}\right), 5.5\left(\mathrm{SiMe}_{3}\right)$, $1.6\left(\mathrm{SiMe}_{2}\right), 0.8\left(\mathrm{SiMe}_{2}\right) .{ }^{29} \mathrm{Si}-\mathrm{NMR}(\delta \mathrm{in} \mathrm{ppm}): 17.2\left(\mathrm{Si}^{i}{ }^{i} \mathrm{Pr}_{3}\right),-9.3\left(\mathrm{SiMe}_{3}\right),-35.3\left(\mathrm{SiMe}_{2}\right),-127.8\left(\mathrm{Si}_{\mathrm{q}}\right)$. UV absorption: $\lambda_{1}=250 \mathrm{~nm}\left(\varepsilon_{1}=8.8 \times 10^{3} \mathrm{M}^{-1} \cdot \mathrm{cm}^{-1}\right)$, shoulder: $267 \mathrm{~nm}\left(\varepsilon=3.2 \times 10^{3} \mathrm{M}^{-1} \cdot \mathrm{cm}^{-1}\right)$.

1,1,4,4-Tetrakis(trimethylsilyl)-2,3-diphenyltetramethylcyclopentasilane (22). A benzene ( $5 \mathrm{~mL}$ ) solution of 18 (283 mg, $0.38 \mathrm{mmol}), \mathrm{KO}^{t} \mathrm{Bu}(88 \mathrm{mg})$, and 18-crown-6 $(208 \mathrm{mg})$ is stirred for $12 \mathrm{~h}$ after which the conversion to 2,5-bis(trimethylsilyl)-3,4-diphenyloctamethylhexasilyl 2,5-dipotassium (18a) is complete as could be proved by NMR. (18a: ${ }^{1} \mathrm{H}-\mathrm{NMR}(\delta$ in ppm): $6.70(\mathrm{~m}, 10 \mathrm{H}), 1.11(\mathrm{~s}, 6 \mathrm{H}, \mathrm{SiMePh}),-0.03$ $\left(\mathrm{s}, 36 \mathrm{H}, \mathrm{SiMe}_{3}\right) .{ }^{29} \mathrm{Si}-\mathrm{NMR}\left(\delta\right.$ in ppm): $-5.0\left(\mathrm{SiMe}_{3}\right),-22.7(\mathrm{SiMePh}),-180.5\left(\mathrm{Si}_{\mathrm{q}}\right)$.)

This solution was added dropwise to dichlorodimethylsilane (45 $\mathrm{mg}, 0.35 \mathrm{mmol}$ ) in toluene $(2 \mathrm{~mL})$. After $24 \mathrm{~h}$ same work up procedure as for 5 and crystallization out of acetone at rt. yielded colorless crystalline 22 (213 mg, 85\%). Mp: $194-197{ }^{\circ} \mathrm{C} .{ }^{1} \mathrm{H}-\mathrm{NMR}$ ( $\delta$ in ppm): 7.00-7.70 (mp, 10H), 0.81 (s, 6H, SiMePh), 0.64 (s, 6H, SiMe $), 0.36$ (s, 18H, $\left(\mathrm{SiMe}_{3}\right), 0.14$ (s, 18H, $\left.\mathrm{SiMe}_{3}\right) .{ }^{13} \mathrm{C}-\mathrm{NMR}(\delta$ in ppm): 138.7, 135.4, 128.3, 127.8, 4.2 (SiMePh), 4.1 ( $\left.\mathrm{SiMe}_{3}\right), 3.5\left(\mathrm{SiMe}_{2}\right),-1.1\left(\mathrm{SiMe}_{2}\right) .{ }^{29} \mathrm{Si}-\mathrm{NMR}(\delta$ in ppm): -6.6 $\left(\mathrm{SiMe}_{3}\right),-8.1\left(\mathrm{SiMe}_{3}\right),-23.4(\mathrm{SiMePh}),-20.7(\mathrm{SiMePh}),-127.6\left(\mathrm{Si}_{\mathrm{q}}\right)$. Anal. calcd. for $\mathrm{C}_{28} \mathrm{H}_{58} \mathrm{Si}_{9}(647.54)$ : C 51.94, H 9.03. Found: C 50.73, H 8.86. UV absorption: shoulder: $\lambda=256 \mathrm{~nm}\left(\varepsilon=1.0 \times 10^{4} \mathrm{M}^{-1} \cdot \mathrm{cm}^{-1}\right)$.

2-(tert-Butyldiphenylsilyl)-2-(trimethylsilyl)hexamethyltrisilane (23). Tetrakis(trimethyl-silyl)-silane (2.00 g, $6.23 \mathrm{mmol}), \mathrm{KO}^{t} \mathrm{Bu}(721 \mathrm{mg}, 6.41 \mathrm{mmol})$ and 18-crown-6 $(1.69 \mathrm{~g}, 6.41 \mathrm{mmol})$ were dissolved in toluene $(20 \mathrm{~mL})$. After NMR showed complete formation of hypersilyl potassium, this orange solution was added dropwise to tert-butylchlorodiphenylsilane in toluene $(10 \mathrm{~mL})$ at $-60{ }^{\circ} \mathrm{C}$. The reaction mixture was allowed to warm to room temperature. After $6 \mathrm{~h}$ same work up procedure as for 5 and crystallization out of acetone yielded colorless crystalline 23 (3.25 g, 69\%). Mp: 342-345 ${ }^{\circ} \mathrm{C}$. ${ }^{1} \mathrm{H}-\mathrm{NMR}$ ( $\delta$ in ppm, $\left.\mathrm{CDCl}_{3}\right): 7.64(\mathrm{~m}, 4 \mathrm{H}), 7.35(\mathrm{~m}, 6 \mathrm{H}), 1.10\left(\mathrm{~s}, 9 \mathrm{H},\left({ }^{t} \mathrm{Bu}\right), 0.12\left(\mathrm{~s}, 27 \mathrm{H},\left(\mathrm{Me}_{3} \mathrm{Si}\right) \cdot{ }^{13} \mathrm{C}-\mathrm{NMR}(\delta\right.\right.$ in ppm, $\left.\mathrm{CDCl}_{3}\right): 137.2,137.1,128.7,127.2,29.4\left(\mathrm{Me}_{3}-\mathrm{C}\right), 20.2\left(\mathrm{Me}_{3}-\mathrm{C}\right), 3.6\left(\mathrm{Me}_{3} \mathrm{Si}\right) .{ }^{29} \mathrm{Si}-\mathrm{NMR}(\delta$ in ppm, 
$\left.\mathrm{CDCl}_{3}\right): 3.7\left({ }^{t} \mathrm{BuPh}_{2} \mathrm{Si}\right),-9.4\left(\mathrm{Me}_{3} \mathrm{Si}\right),-134.1\left(\left(\mathrm{Me}_{3} \mathrm{Si}\right)_{3} \mathrm{Si}\right)$. Anal. calcd. for $\mathrm{C}_{25} \mathrm{H}_{46} \mathrm{Si}_{5}$ (487.07): C 61.65, H 9.52. Found: C 60.93, H 9.38. UV absorption: $\lambda=239 \mathrm{~nm}\left(\varepsilon=1.22 \times 10^{4} \mathrm{M}^{-1} \cdot \mathrm{cm}^{-1}\right)$.

2-(2'-exo-Norbornyldimethylsilyl)-2-(triisopropylsilyl)hexamethyltrisilane (24). A solution of tris(trimethylsilyl) triisopropylsilylsilane $(639 \mathrm{mg}, 1.58 \mathrm{mmol})$ and $\mathrm{KO}^{t} \mathrm{Bu}(186 \mathrm{mg} 1.66 \mathrm{mmol})$ in DME $(10 \mathrm{~mL})$ was stirred at $60{ }^{\circ} \mathrm{C}$ for $1 \mathrm{~h}$. This solution was transferred into a dropping funnel and added slowly to a solution of dimethyl-2-exo-norbornylchlorosilane in DME $(5 \mathrm{~mL})$. After $18 \mathrm{~h}$, the same work-up procedure as for 5 yielded a colorless oil of $\mathbf{2 4}(529 \mathrm{mg}, 69 \%)$. Crystallization with acetone gave colorless plates suitable for X-ray analysis. Mp: $110-112{ }^{\circ} \mathrm{C} .{ }^{1} \mathrm{H}-\mathrm{NMR}\left(\delta\right.$ in ppm): $1.50-2.50\left(\mathrm{~m}, 11 \mathrm{H}, \mathrm{C}_{7} \mathrm{H}_{11} \mathrm{Si}\right), 1.28(\mathrm{sept}, 3 \mathrm{H}$, $\left.\mathrm{SiCH}\left(\mathrm{CH}_{3}\right)_{2}\right), 1.18\left(\mathrm{~d},{ }^{2} J_{\mathrm{HH}}=6.9 \mathrm{~Hz}, 18 \mathrm{H}, \mathrm{SiCH}\left(\mathrm{CH}_{3}\right)_{2}\right), 0.34$ and 0.33 (s, each $\left.9 \mathrm{H}, \mathrm{Si}\left(\mathrm{CH}_{3}\right)_{3}\right) 0.31$ and 0.25 (s, each $\left.3 \mathrm{H}, \mathrm{SiMe}_{2}\right) .{ }^{13} \mathrm{C}-\mathrm{NMR}$ ( $\delta$ in ppm): 39.1, 38.0, 37.0, 34.0, 33.9, 29.8, $28.9\left(\mathrm{Si}\left(\mathrm{CH}_{3}\right)_{2} \mathrm{C}_{7} \mathrm{H}_{11}\right)$, $20.2\left(\mathrm{SiCH}\left(\mathrm{CH}_{3}\right)_{2}\right), 14.8\left(\mathrm{SiCH}\left(\mathrm{CH}_{3}\right)_{2}\right), 4.35$ and $4.31\left(\mathrm{Si}\left(\mathrm{CH}_{3}\right)_{3}\right), 1.2$ and $0.9\left(\mathrm{Si}\left(\mathrm{CH}_{3}\right)_{2}\right) .{ }^{29} \mathrm{Si}-\mathrm{NMR}(\delta$ in ppm): $13.5\left(\mathrm{Si}^{i} \mathrm{Pr}_{3}\right),-4.9\left(\mathrm{SiMe}_{2}\right),-10.1\left(\mathrm{SiMe}_{3}\right),-134.2\left(\mathrm{SiSi}_{4}\right)$. Anal. calcd. for $\mathrm{C}_{24} \mathrm{H}_{56} \mathrm{Si}_{5}$ (485.14): C 59.42, H 11.64. Found: C 58.58, H 11.67. UV absorption: shoulder: $222 \mathrm{~nm}\left(\varepsilon=1.5 \times 10^{4} \mathrm{M}^{-1} \cdot \mathrm{cm}^{-1}\right)$, $\lambda_{1}=274 \mathrm{~nm}\left(\varepsilon_{1}=2.6 \times 10^{3} \mathrm{M}^{-1} \cdot \mathrm{cm}^{-1}\right)$, shoulder: $283 \mathrm{~nm}\left(\varepsilon=2.3 \times 10^{3} \mathrm{M}^{-1} \cdot \mathrm{cm}^{-1}\right)$.

\section{Conclusions}

One of the interesting aspects of the chemistry of poly- and oligosilanes is the associated property of $\sigma$-bond electron delocalization. In recent studies we have shown that terminal tris(trimethylsilyl)silyl groups of short oligosilanes are able to force the molecules to engage in an all-transoid conformation, which allows a high degree of $\sigma$-bond electron delocalization. In case of longer oligosilanes this directing effect is diminished and a second conformation becomes energetically accessible. When we introduced bulky bis(trimethylsilyl)silylene segments inside the chain as conformational amplifiers, these units produced cisoid turns causing rupture of conjugation. The current study is concerned with alteration of the steric bulk of the end groups and internal substituents. By exchange of trimethylsilyl groups against methyl or triisopropyl groups the polysilane chains become either more flexible or more rigid. This change in conformataional behavior is nicely reflected in the shape and position of the UV-absorption bands. While flexible molecules exhibit broad bands, indicating a larger conformational space the rigid molecules show sharp bands which can be associated with the absorption of more precisely defined conformers. The deliberate introduction of phenyl substituents either in terminal or internal positions causes a bathochromic shift of the absorption bands, which is much more pronounced for internal substitution. Subsequent work on these compounds will be concerned with variable temperature studies of these compounds to investigate their thermochromic behavior.

Supplementary Materials: The following are available online at http://www.mdpi.com/1420-3049/21/8/1079/s1. Crystallographic information for compounds 9, 14, 15, 16a, 17, 18, 18a, 21a, 21b, 22, 23, and 24 in CIF format and crystallographic tables.

Acknowledgments: Support of the study was provided by the Austrian Fonds zur Förderung der wissenschaftlichen Forschung (FWF) via projects I-00669, P-22678 and P-25124.

Author Contributions: The manuscript was written through contributions of all authors. All authors have given approval to the final version of the manuscript. Johann Hlina, Filippo Stella, and Mohammad Aghazadeh Meshgi did all the experiments and analyses. Christoph Marschner and Judith Baumgartner provided supervision, financial support via projects and wrote the paper.

Conflicts of Interest: The authors declare no conflict of interest.

\section{References}

1. West, R. Polysilanes. In Organic Silicon Compounds (1989); Patai, S., Rappoport, Z., Eds.; John Wiley \& Sons, Ltd.: Hoboken, NJ, USA, 1989; Volume 1, pp. 1207-1240.

2. Michl, J.; West, R. Conformations of Linear Chains. Systematics and Suggestions for Nomenclature. Acc. Chem. Res. 2000, 33, 821-823. [CrossRef] [PubMed] 
3. Bande, A.; Michl, J. Conformational Dependence of $\sigma$-Electron Delocalization in Linear Chains: Permethylated Oligosilanes. Chem. Eur. J. 2009, 15, 8504-8517. [CrossRef] [PubMed]

4. Sakurai, H.; Kumada, M. The Ultraviolet Spectra of Some Polysilanes. Bull. Chem. Soc. Jpn. 1964, 37, 1894-1895. [CrossRef]

5. Sakurai, H.; Yamamori, H.; Kumada, M. The Substituent Effect on the Ultraviolet Spectrum of 1,2-Diphenyltetramethyldisilane. Bull. Chem. Soc. Jpn. 1965, 38, 2024-2024. [CrossRef]

6. Kumada, M.; Tamao, K. Aliphatic Polysilanes. Adv. Organomet. Chem. 1968, 6, 19-117.

7. Gilman, H.; Atwell, W.H.; Schwebke, G.L. Ultraviolet properties of compounds containing the silicon-silicon bond. J. Organomet. Chem. 1964, 2, 369-371. [CrossRef]

8. Gilman, H.; Atwell, W.H. The ultraviolet properties of some perphenylated linear and cyclic polysilanes. J. Organomet. Chem. 1965, 4, 176-178. [CrossRef]

9. Miller, R.D.; Michl, J. Polysilane high polymers. Chem. Rev. 1989, 89, 1359-1410. [CrossRef]

10. Marschner, C.; Baumgartner, J.; Wallner, A. Structurally and conformationally defined small methyl polysilanes. Dalton Trans. 2006, 5667-5674. [CrossRef] [PubMed]

11. Baumgartner, J.; Fischer, R.; Fischer, J.; Wallner, A.; Marschner, C.; Flörke, U. Structural Aspects of Trimethylsilylated Branched Group 14 Compounds. Organometallics 2005, 24, 6450-6457. [CrossRef]

12. Wallner, A.; Hoelbling, M.; Baumgartner, J.; Marschner, C. Structural and spectroscopic studies of silylated cyclo- and bicyclosilanes. Silicon Chem. 2007, 3, 175-185. [CrossRef]

13. Wallner, A.; Wagner, H.; Baumgartner, J.; Marschner, C.; Rohm, H.W.; Kockerling, M.; Krempner, C. Structure, Conformation, and UV Absorption Behavior of Partially Trimethylsilylated Oligosilane Chains. Organometallics 2008, 27, 5221-5229. [CrossRef]

14. Wallner, A.; Hlina, J.; Konopa, T.; Wagner, H.; Baumgartner, J.; Marschner, C.; Flörke, U. Cyclic and Bicyclic Methylpolysilanes and Some Oligosilanylene-Bridged Derivatives. Organometallics 2010, 29, 2660-2675. [CrossRef]

15. Wallner, A.; Hlina, J.; Wagner, H.; Baumgartner, J.; Marschner, C. Conformational Control of Polysilanes: The Use of $\mathrm{CH}_{2}$-Spacers in the Silicon Backbone. Organometallics 2011, 30, 3930-3938. [CrossRef] [PubMed]

16. Wallner, A.; Emanuelsson, R.; Baumgartner, J.; Marschner, C.; Ottosson, H. Coupling of Disilane and Trisilane Segments Through Zero, One, Two, and Three Disilanyl Bridges in Cyclic and Bicyclic Saturated Carbosilanes. Organometallics 2013, 32, 396-405. [CrossRef]

17. Hlina, J.; Zitz, R.; Wagner, H.; Stella, F.; Baumgartner, J.; Marschner, C. $\sigma$-Bond electron delocalization of branched oligogermanes and germanium containing oligosilanes. Inorg. Chim. Acta 2014, 422, 120-133. [CrossRef] [PubMed]

18. Marschner, C. Preparation and Reactions of Polysilanyl Anions and Dianions. Organometallics 2006, 25, 2110-2125. [CrossRef]

19. Kayser, C.; Fischer, R.; Baumgartner, J.; Marschner, C. Tailor-made Oligosilyl Potassium Compounds. Organometallics 2002, 21, 1023-1030. [CrossRef]

20. Marschner, C. A New and Easy Route to Polysilanylpotassium Compounds. Eur. J. Inorg. Chem. 1998, 221-226. [CrossRef]

21. Wagner, H.; Baumgartner, J.; Marschner, C.; Poelt, P. Rearrangement/Fragmentation Reactions of Oligosilanes with Aluminum Chloride. Organometallics 2011, 30, 3939-3954. [CrossRef] [PubMed]

22. Rooklin, D.W.; Schepers, T.; Raymond-Johansson, M.K.; Michl, J. Time-dependent density functional theory treatment of the first UV absorption band in all-transoid permethyloligosilanes $S_{n} M_{2 n+2}(n=2-8,10)$. Photochem. Photobiol. Sci. 2003, 2, 511-517. [CrossRef] [PubMed]

23. Fukazawa, A.; Tsuji, H.; Tamao, K. all-anti-Octasilane: Conformation Control of Silicon Chains Using the Bicyclic Trisilane as a Building Block. J. Am. Chem. Soc. 2006, 128, 6800-6801. [CrossRef] [PubMed]

24. Tsuji, H.; Fukazawa, A.; Yamaguchi, S.; Toshimitsu, A.; Tamao, K. all-anti-Pentasilane: Conformation Control of Oligosilanes Based on the Bis(tetramethylene)-Tethered Trisilane Unit. Organometallics 2004, 23, 3375-3377. [CrossRef]

25. Mallesha, H.; Tsuji, H.; Tamao, K. UV Absorption and Mass Spectra of n-Alkylsilyl End-Capped Anti, Cisoid-Alternating Oligosilanes up to Docosasilane ( $\left.\mathrm{Si}_{22}\right)$. Organometallics 2004, 23, 1639-1642. [CrossRef]

26. Tsuji, H.; Terada, M.; Toshimitsu, A.; Tamao, K. $\sigma \sigma^{*}$ Transition in anti,cisoid Alternating Oligosilanes: Clear-Cut Evidence for Suppression of Conjugation Effect by a cisoid Turn. J. Am. Chem. Soc. 2003, 125, 7486-7487. [CrossRef] [PubMed] 
27. Tsuji, H.; Michl, J.; Tamao, K. Recent experimental and theoretical aspects of the conformational dependence of UV absorption of short chain peralkylated oligosilanes. J. Organomet. Chem. 2003, 685, 9-14. [CrossRef]

28. Suto, S.; Suzuki, H.; Ono, R.; Shimizu, M.; Goto, T.; Watanabe, A.; Matsuda, M. Exciton Dynamics and Lattice Relaxation in Oligosilanes. Int. J. Mod. Phys. B 2001, 15, 4025-4028. [CrossRef]

29. Krempner, C.; Chtchian, S.; Reinke, H. First synthesis of a dihydrido functionalized double-cored oligosilane dendrimer. Inorg. Chim. Acta 2004, 357, 3733-3738. [CrossRef]

30. Apeloig, Y.; Bravo-Zhivotovskii, D.; Yuzefovich, M.; Bendikov, M.; Shames, A.I. Polysilyl radicals: EPR study of the formation and decomposition of star polysilanes. Appl. Magn. Reson. 2000, 18, 425-434. [CrossRef]

31. West, R. Electron delocalization and "aromatic" behavior in cyclic polysilanes. Pure Appl. Chem. 1982, 54, 1041-1050. [CrossRef]

32. Zirngast, M.; Baumgartner, J.; Marschner, C. Synthesis of Cyclic and Bicyclic Polysilanes of Variable Ring Sizes. Organometallics 2008, 27, 6472-6478. [CrossRef]

33. Fischer, R.; Konopa, T.; Ully, S.; Baumgartner, J.; Marschner, C. Route $\mathrm{Si}_{6}$ revisited. J. Organomet. Chem. 2003, 685, 79-92. [CrossRef]

34. Fischer, R.; Konopa, T.; Ully, S.; Wallner, A.; Baumgartner, J.; Marschner, C. Preparation and structural studies on cyclohexasilane compounds. In Organosilicon Chemistry VI; Auner, N., Weis, J., Eds.; Wiley-VCH: Weinheim, Germany, 2005; pp. 355-360.

35. Lambert, J.B.; Pflug, J.L.; Allgeier, A.M.; Campbell, D.J.; Higgins, T.B.; Singewald, E.T.; Stern, C.L. A Branched Polysilane. Acta Cryst. C 1995, 51, 713-715. [CrossRef]

36. Wagner, H.; Baumgartner, J.; Müller, T.; Marschner, C. Shuttling Germanium Atoms into Branched Polysilanes. J. Am. Chem. Soc. 2009, 131, 5022-5023. [CrossRef] [PubMed]

37. Whittaker, S.M.; Brun, M.-C.; Cervantes-Lee, F.; Pannell, K.H. Synthesis, structure, and reactivity of the permethylated decasilane $\left.\left(\mathrm{Me}_{3} \mathrm{Si}\right)_{3} \mathrm{SiSiMe}_{2} \mathrm{SiMe}_{2} \mathrm{SiMe}_{3}\right)_{3}$. J. Organomet. Chem. 1995, 499, 247-252. [CrossRef]

38. Zirngast, M.; Flock, M.; Baumgartner, J.; Marschner, C. Formation of Formal Disilene Fluoride Adducts. J. Am. Chem. Soc. 2008, 130, 17460-17470. [CrossRef] [PubMed]

39. Wagner, H.; Wallner, A.; Fischer, J.; Flock, M.; Baumgartner, J.; Marschner, C. Rearrangement of Cyclic Silanes with Aluminum Trichloride. Organometallics 2007, 26, 6704-6717. [CrossRef]

40. Stüger, H.; Fuerpass, G.; Renger, K.; Baumgartner, J. Synthesis, Structures, and Unusual Photoluminescence of O- and N-Functional Cyclohexasilanes. Organometallics 2005, 24, 6374-6381. [CrossRef]

41. Dinnebier, R.E.; Dollase, W.A.; Helluy, X.; Kümmerlen, J.; Sebald, A.; Schmidt, M.U.; Pagola, S.; Stephens, P.W.; van Smaalen, S. Order-disorder phenomena determined by high-resolution powder diffraction: The structures of tetrakis(trimethylsilyl)methane $\mathrm{C}\left[\mathrm{Si}\left(\mathrm{CH}_{3}\right)_{3}\right]_{4}$ and tetrakis(trimethylsilyl)silane $\mathrm{Si}\left[\mathrm{Si}\left(\mathrm{CH}_{3}\right)_{3}\right]_{4}$. Acta Cryst. B 1999, 55, 1014-1029. [CrossRef]

42. Fischer, R.; Frank, D.; Gaderbauer, W.; Kayser, C.; Mechtler, C.; Baumgartner, J.; Marschner, C. $\alpha, w-O l i g o s i l y l$ Dianions and Their Application in the Synthesis of Homo- and Heterocyclosilanes. Organometallics 2003, 22, 3723-3731. [CrossRef]

43. Fischer, R.; Konopa, T.; Baumgartner, J.; Marschner, C. Small Cyclosilanes: Syntheses and Reactions toward Mono- and Dianions. Organometallics 2004, 23, 1899-1907. [CrossRef]

44. Aghazadeh Meshgi, M.; Baumgartner, J.; Marschner, C. Oligosilanylsilatranes. Organometallics 2015, 34, 3721-3731. [CrossRef] [PubMed]

45. Krempner, C.; Chisholm, M.H.; Gallucci, J. The multidentate ligand (MeOMe $2 \mathrm{Si}_{3} \mathrm{Si}$-: Unusual coordination modes in alkali metal silanides. Angew. Chem. Int. Ed. 2008, 47, 410-413. [CrossRef] [PubMed]

46. Li, H.; Hope-Weeks, L.J.; Krempner, C. A supramolecular approach to zwitterionic alkaline metal silanides and formation of heterobimetallic silanides. Chem. Commun. 2011, 4117-4119. [CrossRef] [PubMed]

47. Pangborn, A.B.; Giardello, M.A.; Grubbs, R.H.; Rosen, R.K.; Timmers, F.J. Safe and Convenient Procedure for Solvent Purification. Organometallics 1996, 15, 1518-1520. [CrossRef]

48. Gilman, H.; Inoue, S. The Preparation of Some $\alpha, \omega$-Dichloro Permethylated Polysilanes. J. Org. Chem. 1964, 29, 3418-3419. [CrossRef]

49. Marschner, C.; Baumgartner, J. 4.4.5 Product Subclass 5: Disilanes and Oligosilanes. In Science of Synthesis: Houben-Weyl Methods of Molecular Transformations; Oestreich, M., Ed.; Thieme: Stuttgart, Germany, 2013.

50. Gilman, H.; Smith, C.L. Tetrakis(trimethylsilyl)silane. J. Organomet. Chem. 1967, 8, 245-253. [CrossRef]

51. Kayser, C.; Kickelbick, G.; Marschner, C. Simple Synthesis of Oligosilyl- $\alpha, \omega$-dipotassium Compounds. Angew. Chem. Int. Ed. 2002, 41, 989-992. [CrossRef] 
52. Baumgartner, J.; Frank, D.; Kayser, C.; Marschner, C. Comparative Study of Structural Aspects of Branched Oligosilanes. Organometallics 2005, 24, 750-761. [CrossRef]

53. Derouiche, Y.; Lickiss, P.D. Preparation and reactions of tris(trimethylsilyl)silyl silicon derivatives and related tetrasilylsilanes. J. Organomet. Chem. 1991, 407, 41-9. [CrossRef]

54. Gilman, H.; Shiina, K.; Aoki, D.; Gaj, B.J.; Wittenberg, D.; Brennan, T. Hexasubstituted disilanes from chlorosilanes and lithium in tetrahydrofuran. J. Organomet. Chem. 1968, 13, 323-328. [CrossRef]

55. Morris, G.A.; Freeman, R. Enhancement of nuclear magnetic resonance signals by polarization transfer. J. Am. Chem. Soc. 1979, 101, 760-762. [CrossRef]

56. Helmer, B.J.; West, R. Enhancement of silicon-29 NMR signals by proton polarization transfer. Organometallics 1982, 1, 877-879. [CrossRef]

57. SAINTPLUS: Software Reference Manual, version 6.45; Bruker-AXS: Madison, WI, USA; pp. 1997-2003.

58. Blessing, R.H. An empirical correction for absorption anisotropy. Acta Cryst. A 1995, 51, 33-38. [CrossRef]

59. Sheldrick, G.M. SADABS, version 2.10; Bruker AXS Inc.: Madison, WI, USA, 2003.

60. Sheldrick, G.M. A short history of SHELX. Acta Cryst. A 2008, 64, 112-122. [CrossRef] [PubMed]

61. Farrugia, L.J. WinGX and ORTEP for Windows: An update. J. Appl. Cryst. 2012, 45, 849-854. [CrossRef]

62. POVRAY 3.6; Persistence of Vision Pty. Ltd.: Williamstown, Victoria, Australia, 2004. Available online: http://www.povray.org/download/ (accessed on 9 July 2008).

Sample Availability: Not available.

(C) 2016 by the authors; licensee MDPI, Basel, Switzerland. This article is an open access article distributed under the terms and conditions of the Creative Commons Attribution (CC-BY) license (http://creativecommons.org/licenses/by/4.0/). 